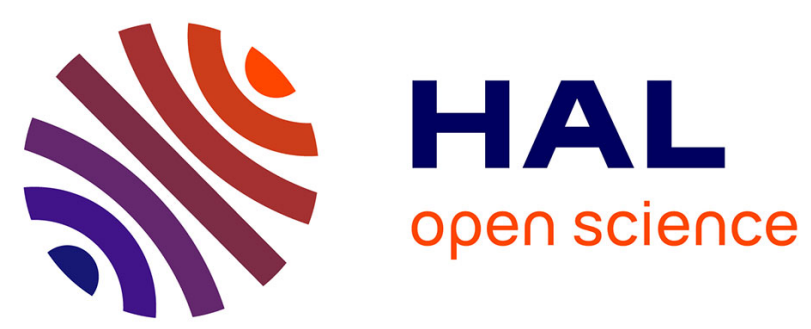

\title{
Organic matter sources and early diagenetic degradation in a tropical peaty marsh (Tritrivakely, Madagascar). Implications for environmental reconstruction during the Sub-Atlantic
}

Sonia Bourdon, Fatima Laggoun-Défarge, Ousmane Maman, Jean-Robert

Disnar, Bernard Guillet, Sylvie Derenne, Claude Largeau

\section{To cite this version:}

Sonia Bourdon, Fatima Laggoun-Défarge, Ousmane Maman, Jean-Robert Disnar, Bernard Guillet, et al.. Organic matter sources and early diagenetic degradation in a tropical peaty marsh (Tritrivakely, Madagascar). Implications for environmental reconstruction during the Sub-Atlantic. Organic Geochemistry, 2000, 31, pp.421-438. 10.1016/S0146-6380(00)00010-3 . hal-00091221

\section{HAL Id: hal-00091221 \\ https://hal-insu.archives-ouvertes.fr/hal-00091221}

Submitted on 12 Feb 2013

HAL is a multi-disciplinary open access archive for the deposit and dissemination of scientific research documents, whether they are published or not. The documents may come from teaching and research institutions in France or abroad, or from public or private research centers.
L'archive ouverte pluridisciplinaire HAL, est destinée au dépôt et à la diffusion de documents scientifiques de niveau recherche, publiés ou non, émanant des établissements d'enseignement et de recherche français ou étrangers, des laboratoires publics ou privés. 


\title{
Organic matter sources and early diagenetic degradation in a tropical peaty marsh (Tritrivakely, Madagascar). Implications for environmental reconstruction during the Sub-Atlantic
}

\author{
$\underline{\text { Sonia Bourdon }}^{\mathrm{a}}$, Fatima Laggoun-Défarge ${ }^{\mathrm{a}}$ Jean-Robert Disnar $^{\mathrm{a}}$ Ousmane Maman $^{\mathrm{a}}$ \\ Bernard Guillet $^{\mathrm{a}}$ Sylvie Derenne ${ }^{\mathrm{b}}$ Claude Largeau ${ }^{\mathrm{b}}$ \\ - ${ }^{a}$ Sédimentation et Diagenèse de la Matière Organique, UMR CNRS 6531, Université \\ d'Orléans, $B^{t}$ de Géosciences, rue de $S^{t}$ Amand, BP 6759, 45067 Orléans cedex 2, \\ France \\ - ${ }^{\mathrm{b}}$ Laboratoire de Chimie Bioorganique et Organique Physique, UMR CNRS 7573, \\ E.N.S.C.P., rue P. et M. Curie, 75231 Paris cedex 05, France
}

\begin{abstract}
Peat samples from a one metre core and living Cyperaceae, collected in Tritrivakely marsh in Madagascar, were studied to determine the organic matter (OM) composition and extent of OM degradation in this core. The study was carried out combining light microscopy observations, bulk analyses, infra-red spectroscopy, hydrolyses of sugars, oxidation of lignin and pyrolyses. In the surface peat, organic matter derived from Cyperaceae undergoes extensive degradation of its basic cell wall components, morphologically revealed by destructuration of plant tissues and their transformation into reddish amorphous organic matter occurring in large amounts all along the core. Two ratios (cinnamic units/lignin and xylose+arabinose/total sugars) were determined as markers of Cyperaceae. It appeared that the vegetation of the marsh remained probably unchanged during the considered accumulation period, i.e. the last 2300 years B.P. Rhamnose, mannose and non-cellulosic glucose probably have a common origin and are mostly derived from bacteria. In contrast, galactose is likely to be a marker of algal source, especially of the diatoms that occur only in the upper part of the core $(0-$ ca. $50 \mathrm{~cm})$. Acid/aldehyde ratios of syringic and vanillic monomers (index of lignin oxidative depolymerisation) and mannose+rhamnose+non-cellulosic glucose/total sugars ratios (reflecting bacterial degradation of hemicelluloses) are positively correlated, and can thus be considered as markers of microbial degradation of the Cyperaceae tissues. The $n$ alkane $/ n$-alk-1-ene doublets that dominate the pyrolysates of hydrolysed peat samples reflect the contribution of $B$. braunii algaenan and higher plant suberans, and of condensed lipids mostly derived from higher plants and microalgae. The upper part of the core is characterised by a greater dilution of Cyperaceae-derived compounds by organic matter from microalgae when compared with deeper samples, as recorded by peat bulk features, hydrolysable sugars, lignin oxidation products and pyrolysis products. Two accumulation periods can thus be distinguished in the core: a peaty phase between 2300 years B.P. and ca. 1500 years B.P. (low watertable and strongly limited microalgal growth); a waterlogged marsh, from ca. 1500 years B.P. to the present time, in which a higher water table was longer lasting with a substantial algal production. The environmental variation thus recorded could correspond to a regional climatic change occurring around 1500 years B.P.
\end{abstract}

\section{Keywords}

Tritrivakely lake; Peat; Cyperaceae; Diatoms; Botryococcus braunii; Organic matter sources;

Early diagenesis; Sugar hydrolysis; Lignin oxidation; Pyrolyses 


\section{Introduction}

Various components of organic matter $(\mathrm{OM})$ in sediments and soils can be used as phytoecological indicators for the reconstruction of palaeoenvironments and palaeoclimates (e.g. Hedges \& Mann, 1979, Pelet \& Deroo, 1983 and Huc, 1988). Interpretation of OM records for such a purpose requires the identification of OM sources, information on their diagenetic alteration and estimation of their contribution to total OM. In peats and lacustrine sediments, the main primary sources of OM are (1) planktonic and benthic algae, (2) terrestrial plant remains and soil OM reworked from the catchment area and (3) submerged and/or emergent vascular plants which may colonise lake margins or the whole water-body in the case of mires and marshes. During transport to the lake or to the marsh as well as during deposition and early diagenesis, many processes may alter the original characters of organic sources. In peatlands, OM preservation is favoured by an anoxic environment and rapid burial (Clymo, 1983). However, anaerobic bacterial processes (i.e. fermentation, sulphate reduction and/or methanogenesis) may significantly modify elemental, molecular and isotopic composition of residual OM ( Colberg, Young, 1982 and Benner, MacCubbin \& Hodson, 1984). Studies of lipid biomarkers in peat were recently performed to reconstruct higher plant inputs so as to derive new climatic change proxies ( Farrimond \& Flanagan, 1995 and Ficken, Barber 7 Eglinton, 1998).

Peat precursors are mainly terrestrial higher plants, except for Sphagnum peat. OM in peat is therefore, mostly composed of products derived from lignin, hemicelluloses and cellulose. It may also comprise plankton-derived $\mathrm{OM}$ which contains a significant fraction of carbohydrates, even if their amount is lower when compared with vascular plants (Hamilton and Hedges, 1988). Depending on OM sources (terrestrial or planktonic) and types of vascular plant tissues, monomer components of these polysaccharides exhibit distinctive compositional patterns ( Moers, Baas, Boon \& De Leeuw, 1990a and Moers, Baas, de Leeuw, Boon \& Schenck, 1990).

Lignin which is a major component of vascular plant tissues, is a highly-branched phenol polymer that is present in diverse molecular associations. Variations are due to different proportions of coniferyl, sinapyl and $p$-coumaryl alcohol-derived compounds in gymnosperm, di- and monocotyledon angiosperm lignins. The distribution of lignin-derived monomeric phenolic compounds can be determined through oxidative hydrolysis of the lignin polymer, generally performed by $\mathrm{CuO}$ in alkaline medium. Monomer distributions have been used for the characterisation of different vascular plants and tissue types (Hedges and Mann, 1979) and for the determination of the sources and degradation intensity of OM in soils and sediments (Ertel and Hedges, 1984). To date, only a few attemps have been made to use lignin-derived compounds to examine changes in terrestrial vegetation type resulting from variations of palaeoenvironmental conditions ( Hedges, Ertel \& Leopold, 1982, Ishiwatari \&, Uzaki, 1987, Oades, 1984 and Maman, Guillet, Dismar, Marseille \& Mariotti, 1998), especially in hydromorphic environments such as peatlands.

This study aims to characterise the nature and early degradation processes of OM from a continental peaty marsh (Tritrivakely lake, Madagascar) in order to determine OM sources and to emphasise changes in depositionnal conditions that occurred during the past two millenia. At the present time, this marsh is colonised by Cyperaceae. Peat samples from the upper metre of the deposit were compared with material isolated from fresh Cyperaceae (Cyperus madagariensis, Cyperus papyrus and Heliocharis equisetina) now growing at the site, and changes in peat characteristics with depth were also examined in this section. Bulk 
characterisation, in terms of $\mathrm{C} / \mathrm{N}$ ratio, hydrogen index and micromorphological features, of peats and fresh material were carried out first. Secondly, specific signatures of carbohydrates as well as lignin-derived phenolic compounds were used to provide indications as to sources and preservation state of peat OM through comparison with fresh material. Finally, the chemical composition of "hydrolysed peat" (insoluble material obtained after extraction by organic solvents and hydrolysis by dilute acid) isolated from two selected levels was examined by analysis of "off-line" pyrolysates via combined gas chromatography/mass spectrometry (GC-MS) in order to complete the information given by the products released upon hydrolysis.

\section{Experimental}

\subsection{Modern setting and sampling}

Tritrivakely lake $\left(1947^{\prime} \mathrm{S}, 46^{\circ} 55^{\prime} \mathrm{E}, 1778 \mathrm{~m}\right)$ is located in the central part of the Ankaratra Plateau (Madagascar). This plateau consists of trachyte and rhyolite domes of Pliocene age and Quaternary basaltic flows covering a metamorphic basement (Besairie, 1946). The lake is a maar about $600 \mathrm{~m}$ wide and $50 \mathrm{~m}$ deep. As revealed by piston-core examination, sedimentary infill represents a more than $40 \mathrm{~m}$ thick accumulation of lacustrine and paludal sediments that have probably recorded the last climatic cycle (Gasse et al. 1994, Sifeddine et al. 1995 and Gasse \& Van Campo, 1998). The uppermost $3 \mathrm{~m}$ of sediment consist of peat accumulated during the late Holocene (Burney, 1987 and Gasse et al. 1994).

The regional climate, controlled by latitude and topography (Donque, 1975), is of the mountain tropical type (mean annual precipitation about $1600 \mathrm{~mm} /$ year; mean annual temperature about $16^{\circ} \mathrm{C}$ ) with a warm and wet summer and a dry and cool winter (Chaperon et al., 1993). The lake has no surface outlet. Changes in water-level are, therefore, directly controlled by the precipitation/evaporation ratio. As a consequence, the watertable varies considerably; the lake was almost dry in November 1992, while the maximum watertable reached $0.6 \mathrm{~m}$ in January 1992, and up to $2 \mathrm{~m}$ after an extremely rainy season in May 1994. Water is fresh, oligotrophic (electric conductivity about $20.6 \mu \mathrm{S} \mathrm{cm}^{-1}$ ), slightly acidic ( $\mathrm{pH}$ from 5.5 to 6.3 ), and has a ${ }^{14} \mathrm{C}$ activity of $98.14 \%$ corresponding to an apparent age of about 1000 years (Gasse et al., 1994). The waterbody is presently colonised by aquatic and emergent plants. The flora mainly consists of Cyperaceae (Cyperus madagariensis dominant, and Cyperus papyrus andHeliocharis equisetina) with some Poaceae species like Leersia hexandra. Rice and corn are cropped on the slopes of the crater.

The present study is concerned with the uppermost metre of peat which has accumulated for 2300 years B.P. in the maar (Bourdon et al., 1997). The studied core was taken in 1994 near the center of the marsh. Samples were taken with a spacing of $5 \mathrm{~cm}$ for Rock-Eval pyrolyses and LECO analyses; the other studies were performed on core sections ( $1-4 \mathrm{~cm}$ thick).

Cyperaceae living in the marsh were also examined. They consisted of Cyperus madagariensis, Cyperus papyrus and Heliocharis equisetina stems. All samples were kept at $4^{\circ} \mathrm{C}$ until they were prepared for microscopy and geochemical analyses.

\subsection{Bulk analyses}

Total organic carbon (TOC) contents and hydrogen index (HI) values were obtained by RockEval pyrolysis and $\mathrm{C} / \mathrm{N}$ ratios with LECO CNS. Elemental analysis $(\mathrm{C}, \mathrm{H}, \mathrm{O}, \mathrm{N}$ and ash) was carried out on two samples selected for detailed analysis, including pyrolysis of the insoluble 
residue from acid hydrolysis. Morphological identification and quantification of peat constituents were carried out by transmitted light microscopy.

\subsection{Sugar analysis}

The labile sugars, including hemicellulosic glucose, were released by hydrolysis at $100^{\circ} \mathrm{C}$ during $3 \mathrm{~h}$ with $0.5 \mathrm{~N} \mathrm{HCl}$ (hydrolysis I). The insoluble solid residues thus obtained were further hydrolysed with $12 \mathrm{~N} \mathrm{HCl}$ at room temperature during $12 \mathrm{~h}$ then, after dilution of the acid to $0.5 \mathrm{~N}$, hydrolysed again under the same conditions as above (hydrolysis II). This second treatment was carried out to remove resistant sugars, beginning with cellulosic glucose (e.g. Sigléo, 1996). After each hydrolysis, a known quantity of inositol, used as an internal standard, was added to the supernatant. Thereafter, water and $\mathrm{HCl}$ were eliminated under vaccuum in a rotary evaporator. After drying 24 to $48 \mathrm{~h}$ in a desiccator, in the presence of $\mathrm{KOH}$, the dried sugars were dissolved in pyridine containing $0.2 \%$ (w:v) lithium perchlorate. The mixture was kept at $40^{\circ} \mathrm{C}$ during $2 \mathrm{~h}$ in order to reach the anomeric equilibrium (Bethge et al., 1966). Then, sugars were silylated at $60^{\circ} \mathrm{C}(1 \mathrm{~h})$ with Tri-sil ${ }^{\circledR}$ Fluka $(1: 2 ; \mathrm{v}: \mathrm{v})$. The silylated sugars were analysed by means of a DI 700 Delsi ${ }^{\circledR}$ gas chromatograph equipped with a CP sil $5 \mathrm{CB}$ column $(0.32 \mathrm{~mm}$ i.d. $\times 30 \mathrm{~m})$ (film thickness $0.25 \mu \mathrm{m})$, a flame ionisation detector $\left(300^{\circ} \mathrm{C}\right)$, and a split/splitless capillary injector maintained at $300^{\circ} \mathrm{C}$ and used in the splitless mode (valve reopened $1 \mathrm{~min}$ after injection). After being held $1 \mathrm{~min}$ at $60^{\circ} \mathrm{C}$, the oven temperature was increased from 60 to $120^{\circ} \mathrm{C}$ at $30^{\circ} \mathrm{C} / \mathrm{min}$, and then from 120 to $300^{\circ} \mathrm{C}$ at $3^{\circ} \mathrm{C} / \mathrm{min}$. The efficiency of sugar release by hydrolyses I and II was tested, on material from living Cyperaceae and on two peat samples $(0-1 \mathrm{~cm}$ and $50-54 \mathrm{~cm})$ by infra-red spectroscopy of solid residues.

\subsection{Lignin analysis}

The release of lignin-derived phenols was achieved via $\mathrm{CuO}$ oxidation (Hedges and Ertel, 1982). Vanillic and syringic compounds are derived from the oxidation of the coniferyl and sinapyl moieties of lignin, respectively, and they consist of ketones, aldehydes and acids. The vanillic (V) and syringic (S) units correspond to the sum of such products. The ferulic and $p$ coumaric acids linked to cellulose by ester-bonds and composing the cinnamic unit (C) were generated from the cinnamyl alcohol-derived moieties. $p$-Hydroxybenzoic compounds were also identified but this unit $(\mathrm{H})$ can be partly derived from other sources than lignin. Total lignin is calculated as the sum of vanillic, syringic, cinnamic and $p$-hydroxybenzoic units.

About $50 \mathrm{mg}$ of bulk peat, in duplicate, were hydrolysed with $\mathrm{NaOH}(8 \%)$ at $170^{\circ} \mathrm{C}$ during 4 $\mathrm{h}$, in the presence of $\mathrm{CuO}$ and Mohr salt (Hedges and Ertel, 1982). After cooling, a known quantity of 2, 4, 5-trimethoxybenzoic acid was added as internal standard. After acidification at $\mathrm{pH}=1$ with $\mathrm{HCl}(6 \mathrm{~N})$ and centrifugation, lignin phenols were extracted with peroxide free diethylether. After ether evaporation in rotary evaporator, lignin phenols were redissolved in methanol and kept under $\mathrm{N}_{2}$ in a tightly closed vessel until analysis. The separation of lignin monomers, i.e. 11 phenolic aldehydes, ketones and acids, was performed by capillary zone electrophoresis according to Maman et al. (1996) with a P/ACE 5510 system (Beckman) equipped with a silica capillary $(57 \mathrm{~cm} \times 50 \mathrm{~mm})$. After a $1 \mathrm{~s}$ injection and separation, phenols were determined by UV detection at $214 \mathrm{~nm}$ through the capillary, at $50 \mathrm{~cm}$ from the injection point. 


\subsection{Pyrolyses}

"Off-line" pyrolyses were performed on the insoluble residues of two selected peat samples (30-34 and 79-80 cm). Residues were obtained after three successive treatments. First, bulk peat was extracted with $\mathrm{CH}_{2} \mathrm{Cl}_{2} /$ methanol $(2: 1 ; \mathrm{v}: \mathrm{v})$ at room temperature to remove free lipids. Then the solvent-extracted material was hydrolysed during $3 \mathrm{~h}$ at $100^{\circ} \mathrm{C}$ with $0.5 \mathrm{~N}$ $\mathrm{HCl}$ to remove the most labile polysaccharides. Finally, a second extraction was performed with $\mathrm{CH}_{2} \mathrm{Cl}_{2}$ :methanol $(2: 1 ; \mathrm{v}: \mathrm{v})$ to remove bound lipids released after hydrolysis. The solid residues thus obtained were submitted to "off-line" pyrolyses (Largeau et al., 1986) via successive heating at $300^{\circ} \mathrm{C}$ for $20 \mathrm{~min}$ and at $400^{\circ} \mathrm{C}$ for $1 \mathrm{~h}$ under a helium flow. After each pyrolysis, the residue was extracted with $\mathrm{CH}_{2} \mathrm{Cl}_{2} /$ methanol $(2: 1 ; \mathrm{v}$ :v). The pyrolysis products formed at $400^{\circ} \mathrm{C}$ and trapped in cold chloroform at $-5^{\circ} \mathrm{C}$ were analysed by GC/MS. GC/MS was carried out on a Hewlett-Packard 5890 gas chromatograph interfaced to a 5989A Hewlett-Packard mass spectrometer operated at $70 \mathrm{eV}$ with a mass range $m / z 40-600$. The gas chromatograph was equipped with a $25 \mathrm{~m}$ CPSil 5 CB column (film thickness: $0.4 \mu \mathrm{m}$ ). Helium was the carrier gas. The oven was heated from 100 to $300^{\circ} \mathrm{C}$ at $4{ }^{\circ} \mathrm{C} \mathrm{min}{ }^{-1}$.

\subsection{Infra-red spectroscopy}

Fourier transform infra-red (FTIR) analysis was carried out with Perkin-Elmer 16 PC apparatus. Untreated materials and insoluble residues from hydrolyses and pyrolyses were examined in order to characterise the loss of labile compounds and the chemical changes occurring upon acid treatment and thermal stress.

\section{Results and discussion}

\subsection{Bulk characterisation}

Light microscopy enabled two main organic fractions to be distinguished in the peat : (1) a major fraction (80-90\%) composed of reddish amorphous OM flakes [Plate 1(a) ] that is present throughout the series and (2) a minor fraction (5-10\%) formed by algal OM, namely

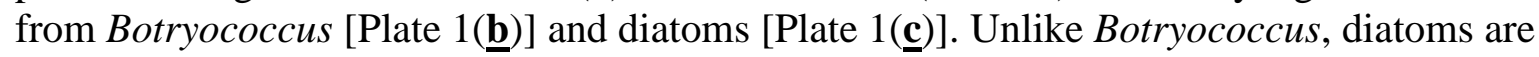
only present in the upper part of the profile ( $\leqslant 55 \mathrm{~cm}$ depth). In addition, the samples of "surface peat" ( $\leqslant 10 \mathrm{~cm})$ contain substantial proportions $(5$ to $15 \%)$ of well-preserved plant tissues, especially from Cyperaceae [Plate $1(\underline{\mathbf{d}})]$. The large predominance of amorphous OM flakes from the first centimetre and throughout the series, indicates that extensive destructuration and alteration of plant tissues occur immediately after the incorporation of senescent plant remains into the peat (Bourdon et al., 1997). Nevertheless, transmission electron microscopy (TEM) observations showed that such flakes contain, in addition to a fraction which appears amorphous even at a nanoscopic scale, preserved biological structures (laminae) probably inherited from plant tissues (Laggoun-Défarge et al., 1999). TEM observations also showed bacterial and/or fungal bodies associated with degraded plant tissues. 

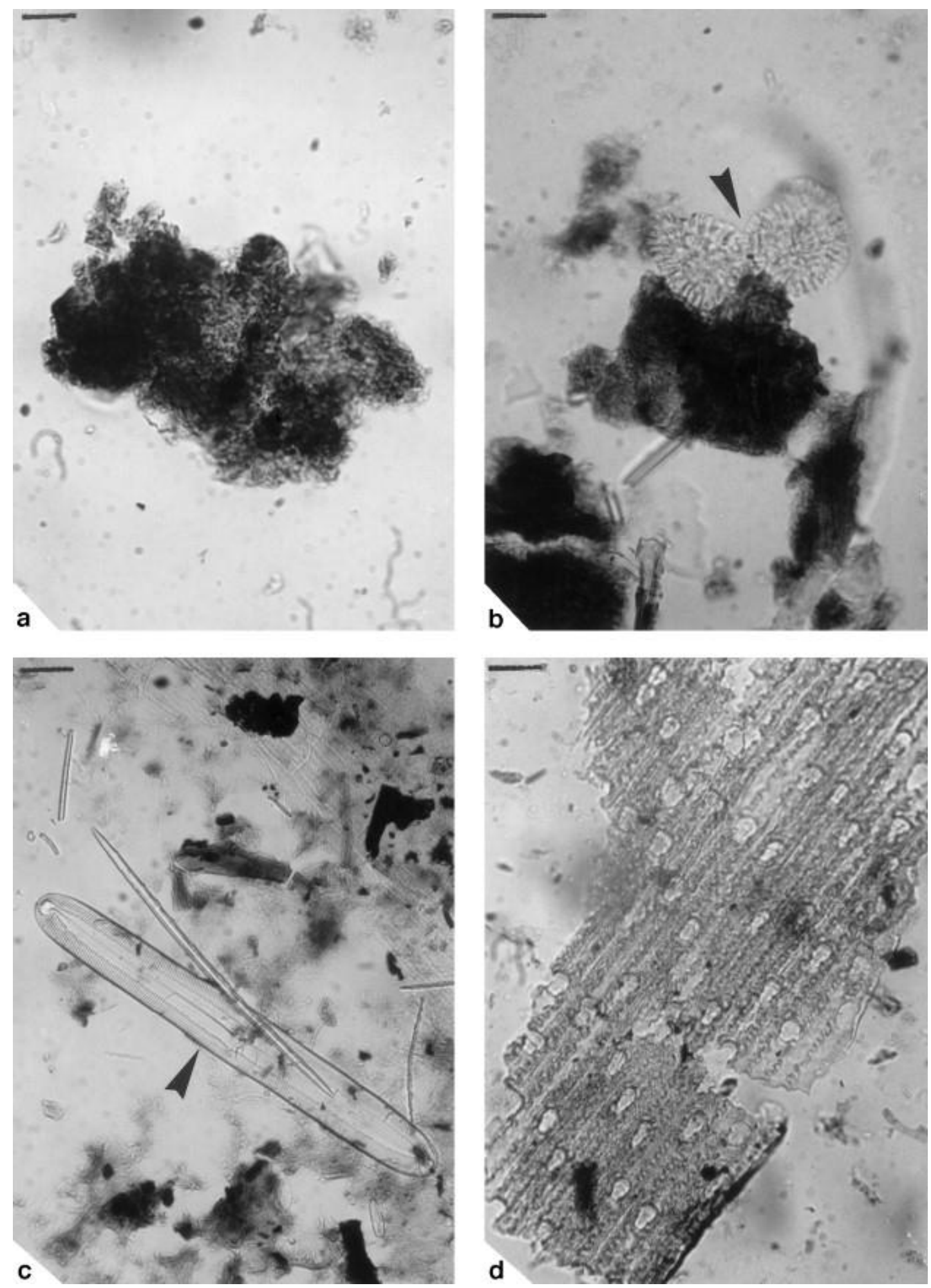

Plate. 1. Micrographs of peat samples from Tritrivakely marsh, Madagascar, obtained by transmitted light microscopy. (a): Amorphous organic matter flakes derived from destructuration and alteration of higher plant tissues and occurring in large amount throughout the peat profile. (b) and (c): Algal organic matter composed of Botryococcus (b) (arrow) and diatoms (c) (arrow) which occurs as a minor fraction in the half upper part of the peat profile. (d): Well-preserved plant tissues of Cyperaceae occurring in substantial proportions in the surface peat $(\leqslant 10 \mathrm{~cm}$ depth). Scale bar $=15 \mu \mathrm{m}$. 
Total organic carbon (TOC) content remains high throughout the series, i.e. between 45 and 50\% (Fig. 1), as usually observed for the accumulation of OM of terrestrial origin, in the absence of notable inorganic inputs. However, hydrogen index (HI) values, which range between 460 and $580 \mathrm{mg} \mathrm{HC/g}$ TOC, are higher than expected for a material believed to be mainly from ligno-cellulosic tissues (Espitalié et al., 1985). In fact, fresh cyperaceae tissues yield a HI value of $360 \mathrm{mg} \mathrm{HC/g}$ TOC. These high $\mathrm{HI}$ values in peat can partly be explained by a substantial contribution of hydrogen-rich algal $\mathrm{OM}$ that is consistent with the above microscopic observations. The relatively high $\mathrm{C} / \mathrm{N}$ ratio of 23 observed in the upper $1 \mathrm{~cm}$ of the peat suggests incomplete degradation of Cyperaceae tissues $(\mathrm{C} / \mathrm{N}$ ratio of 41). Below, complete Cyperaceae degradation and algal OM contribution probably explain the observed $\mathrm{C} / \mathrm{N}$ ratios of $14-18$.

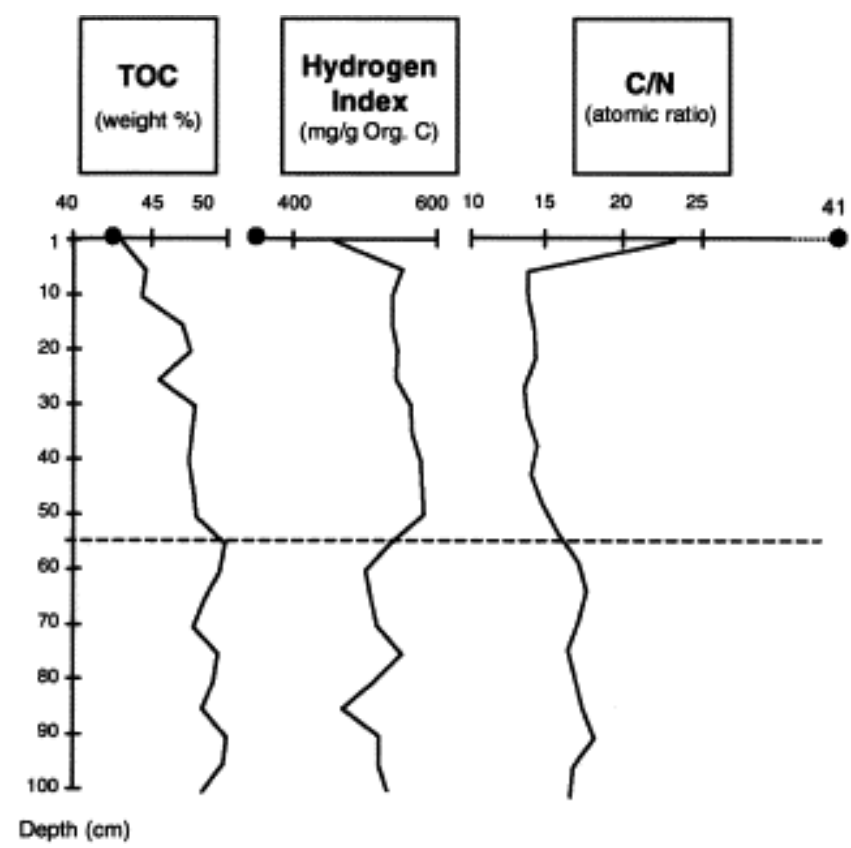

Fig. 1. Comparison of TOC concentrations, Rock Eval hydrogen index (HI) values and organic matter atomic $\mathrm{C} / \mathrm{N}$ ratios in fresh Cyperaceae stems $(\bullet)$ and peat samples from Tritrivakely marsh, Madagascar.

The downward evolution of the above mentioned parameters allows two parts, $0-50 \mathrm{~cm}$ and $50-100 \mathrm{~cm}$, to be distinguished in the series (Fig. 1). The samples from the $0-50 \mathrm{~cm}$ zone, when compared with deeper samples, exhibit higher $\mathrm{HI}$ values and lower $\mathrm{C} / \mathrm{N}$ ratios, thus suggesting a higher algal contribution in the upper part of the profile. This evolution should reflect changes in accumulation conditions of the peat, probably related, as discussed later on, to a regional climatic change.

\subsection{Hydrolysable organic matter}

\subsubsection{Sugars}

The efficiency of sugar hydrolysis was examined by Fourier transform infra-red (FTIR) spectroscopy on three samples : stems of living Cyperaceae, $0-1 \mathrm{~cm}$ and 50-54 cm depth 
peats. The FTIR spectra of the starting materials [1(A), 2(A), 3(A); Fig. 2] are compared with those of the corresponding insoluble residues isolated after the two successive hydrolyses [1(B), 2(B), 3(B); Fig. 2]. All these spectra exhibit intense absorptions around $1040 \mathrm{~cm}^{-1}$ (v C-O) which are assigned to cellulosic sugars (Given et al., 1984). When compared with the untreated materials, some decrease in the relative intensity of these bands is observed in the corresponding solid residues. However, this relative decrease is less pronounced in living Cyperaceae [1(A) and 1(B), Fig. 2] suggesting that cellulosic sugars occur in more resistant polymers in living Cyperaceae than in the peat samples. Such a difference may reflect the extensive destructuration and alteration of plant tissues observed, as discussed above, from the surface of the peat by light microscopy. 

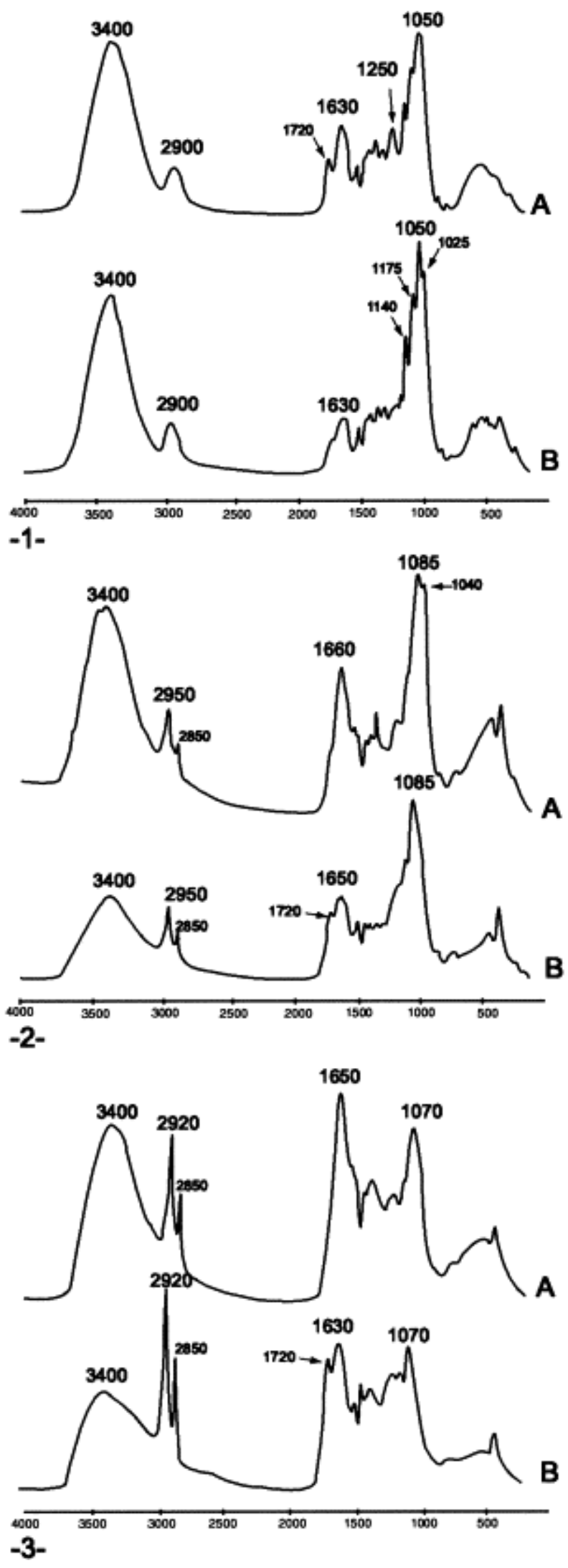

Fig. 2. FTIR spectra of (1) fresh Cyperaceae stems, (2) surface peat (0-1 cm depth) and (3) deep peat (50-54 cm depth) from Tritrivakely marsh, Madagascar. (A) indicates untreated material and (B), insoluble residues from successive hydrolyses with $0.5 \mathrm{~N} \mathrm{HCl}$ and $12 \mathrm{~N} \mathrm{HCl}$. 
As expected, the labile sugars appear to be almost entirely released by hydrolysis I, since the sugars obtained via hydrolysis II are much less abundant and mostly correspond to cellulosic glucose (Table 1). In the material from the living Cyperaceae and in the surface horizon of the peat $(0-1 \mathrm{~cm})$, about $50 \%$ of the organic carbon corresponds to polysaccharides. The larger amounts of labile glucose (glucose I) in the surface horizon than in the Cyperaceae sample $(71.5 \mathrm{mg} / \mathrm{g}$ vs. $52.8 \mathrm{mg} / \mathrm{g}$ ) suggests a contribution from another source to the peat, e.g. from microbiota. The rather low amounts of cellulosic glucose (glucose II) released by the material from the living Cyperaceae (Table 1), can be explained by incomplete hydrolysis. This is supported by the above mentioned strong relative intensity of cellulose bands in the FTIR spectra of the hydrolysis residue of Cyperaceae material (Fig. 2).

Nevertheless, the amount of cellulosic glucose recovered upon hydrolysis II sharply decreases between the latter material and the $0-1 \mathrm{~cm}$ horizon (Table 1), although more efficient hydrolysis is achieved from peat samples as shown by FTIR observations. Accordingly, it appears that cellulose is rapidly and extensively altered upon deposition and the bulk is degraded as early as the surface horizon of the peat.

Table 1. Total sugar yields (mg of C. sugars/g Org. C.) from the two successive hydrolyses: hydrolysis I carried out with $0.5 \mathrm{~N} \mathrm{HCl}$, and hydrolysis II carried out with $12 \mathrm{~N} \mathrm{HCl}$; and total glucose yields (mg of C. glucose/g Org. C.) from these two hydrolyses. Hydrolysis II was carried out to remove especially cellulosic glucose (glucose II)

\begin{tabular}{lllll}
\multicolumn{5}{c}{ C-sugars I C-sugars II C-glucose I C-glucose II } \\
Cyperaceae & 449.0 & 50.5 & 52.8 & 43.6 \\
$0-1 \mathrm{~cm}$ & 496.4 & 10.6 & 71.5 & 7.6 \\
$2-5 \mathrm{~cm}$ & 95.1 & 7.9 & 24.2 & 6.7 \\
$9-12 \mathrm{~cm}$ & 79.3 & 5.2 & 18.9 & 4.7 \\
$13-15 \mathrm{~cm}$ & 75.9 & 1.8 & 15.3 & 1.1 \\
$19-21 \mathrm{~cm}$ & 68.0 & - & 14.7 & 0.0 \\
$30-34 \mathrm{~cm}$ & 78.4 & 2.3 & 17.1 & 1.7 \\
$50-54 \mathrm{~cm}$ & 56.8 & 2.5 & 11.0 & 1.6 \\
$59-60 \mathrm{~cm}$ & 48.4 & 1.2 & 11.7 & 0.8 \\
$79-80 \mathrm{~cm}$ & 55.2 & 3.5 & 12.5 & 1.8 \\
$96-99 \mathrm{~cm}$ & 74.9 & 4.2 & 13.5 & 2.8
\end{tabular}

In the peat, the total sugar content roughly decreases from ca. $510 \mathrm{mg} / \mathrm{g}$ at $0-1 \mathrm{~cm}$ to ca. 100 $\mathrm{mg} / \mathrm{g}$ at $2-5 \mathrm{~cm}$ depth (Table 1 ). Below, the amount of sugars remains roughly constant all along the series. These results, which reflect strong microbial degradation in the surface horizon of the peat, are consistent with previous results obtained on a red mangrove swamp (Moers et al., 1990b).

The relative abundances of the monosaccharides released following the two hydrolyses are listed in Table 2. The living Cyperaceae are characterised by high amounts of hemicellulosic sugars (xylose $\gg$ arabinose > glucose I) compared with cellulosic glucose released by hydrolysis II. An abundant presence of xylose is common for macrophytes since Wicks and his collaborators (1991) found about 50\% of xylose in the total sugars of Juncus effusus, Carex walteriana and Spartina alterniflora. 
Table 2. Monosaccharide concentrations (w\% of total sugars) of fresh Cyperaceae stems compared to those of peat samples from Tritrivakely marsh, Madagascar

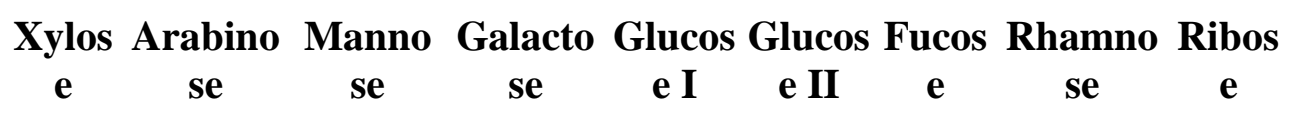

$\begin{array}{llllllllll}\begin{array}{l}\text { Cyperace } \\ \text { ae }\end{array} & 56 & 17 & 1 & 4 & 11 & 9 & 1 & 1 & 0 \\ 0-1 \mathrm{~cm} & 35 & 20 & 4 & 18 & 14 & 1 & 5 & 2 & 0 \\ 2-5 \mathrm{~cm} & 22 & 12 & 8 & 18 & 24 & 7 & 5 & 6 & 0 \\ 9-12 \mathrm{~cm} & 17 & 9 & 8 & 15 & 22 & 6 & 11 & 5 & 6 \\ 13-15 \mathrm{~cm} 25 & 9 & 7 & 13 & 20 & 1 & 16 & 6 & 3 \\ 19-21 \mathrm{~cm} \mathrm{14} & 7 & 6 & 27 & 22 & 0 & 14 & 5 & 5 \\ 30-34 \mathrm{~cm} 15 & 7 & 7 & 26 & 21 & 2 & 14 & 5 & 2 \\ 50-54 \mathrm{~cm} \mathrm{13} & 7 & 7 & 23 & 19 & 3 & 15 & 5 & 7 \\ 59-60 \mathrm{~cm} \mathrm{19} & 10 & 8 & 11 & 24 & 2 & 17 & 7 & 2 \\ 79-80 \mathrm{~cm} \mathrm{17} & 8 & 9 & 14 & 21 & 3 & 14 & 8 & 6 \\ 96-99 \mathrm{~cm} \mathrm{31} & 14 & 6 & 12 & 17 & 3 & 9 & 5 & 2\end{array}$

In the "surface peat" ( $\leqslant 10 \mathrm{~cm})$, xylose and arabinose inherited mainly from the Cyperaceae are still abundant. In addition, large amounts of galactose and non-cellulosic glucose are observed (Table 2).

With increasing depth, while the amounts of arabinose and cellulosic glucose (glucose II) decrease, those of galactose and non-cellulosic glucose (glucose I) increase slightly (Table 2). These latter sugars might indicate a contribution of other sources, corresponding to microalgae and/or microbiota. A microbial contribution might also account for the relatively high proportions of mannose, fucose and rhamnose. Non-cellulosic glucose is a very common constituent in many organisms, e.g. vascular plants, phytoplankton and bacteria. On the other hand, galactose and mannose are frequently related to bacterial or algal sources in soils (Trouvé et al., 1996), mangrove peat (Moers et al., 1990b) and lake sediments (Boschker et al., 1995), while a bacterial source is also commonly considered for the deoxihexoses fucose and rhamnose as it was observed in trap sediments by Hicks et al. (1994).

The close correlation between arabinose and xylose [Fig. 3(A)] confirms that both these compounds are derived from hemicellulosic tissues of Cyperaceae. In the same way, the correlations between rhamnose and mannose [Fig. 3(B)], and between glucose (I) and mannose [Fig. 3(C)] suggest that these monosaccharides probably have a common origin and are chiefly derived from bacteria. The excess of non-cellulosic glucose (ca. 8\%) observed in [Fig. 3(C] probably reflects a vascular plant source. 

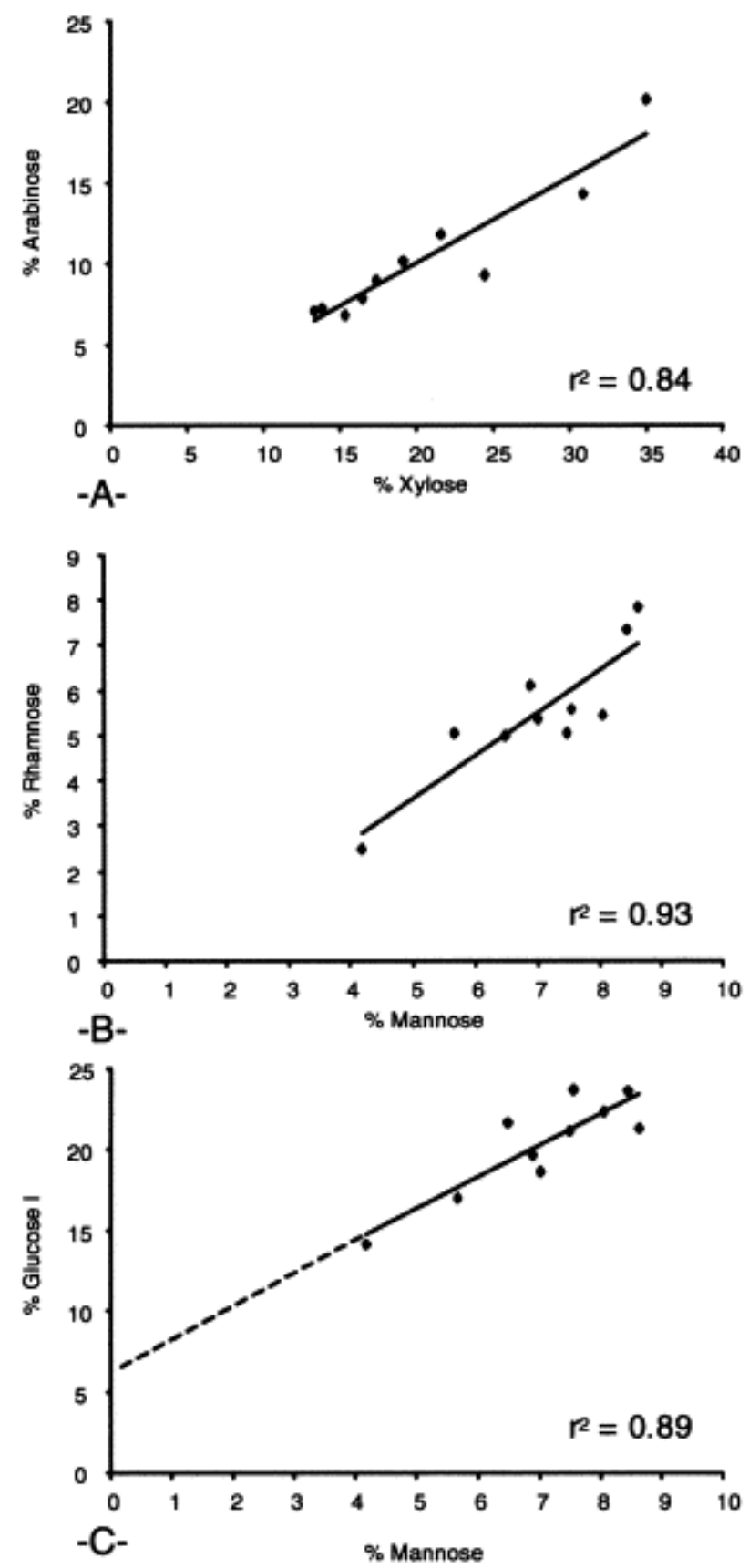

Fig. 3. Relationships between (A) xylose and arabinose, (B) mannose and rhamnose, and (C) mannose and non-cellulosic glucose (glucose I) in peat samples from Tritrivakely marsh, Madagascar. The excess of non-cellulosic glucose content probably originates from a vascular plant source.

The evolution of total sugar content along the profile indicates that extensive degradation of polysaccharides only occurs in the surface peat (the first $\mathrm{cm}$ depth; Table 1). Below, no clear downward evolution is detected for sugars. This might indicate a low in situ microbial activity for sugar degradation, as previously observed in a mangrove swamp (Moers et al., 1990b). The outcome is a remarkable biological stability of the polysaccharidic associations along the profile which is the specificity of hydromorphic environments such as peatlands, compared with aerobic soil environments. 


\subsubsection{Lignin-derived phenols}

The material from the living Cyperaceae shows an unusually high lignin content (ca. 140 $\mathrm{mg} / \mathrm{g} \mathrm{C}$; Table 3), higher than the value (ca. $95 \mathrm{mg} / \mathrm{g} \mathrm{C}$ ) previously obtained by Maman (1997) with two tropical Poaceae: Hyparhenia sp. and Imperata cylindrica. As usual, for monocotyledons, Cyperaceae lignin is dominated by cinnamic units (56\% of total lignin) composed of both $p$-coumaric and ferulic acids (Table 3), and the other most abundant lignin degradation products are syringic and vanillic aldehydes (25\% of total lignin; Table 3 ).

Table 3. Total yield of lignin (mg/g Org. C.) and relative concentrations of lignin $\mathrm{CuO}$ oxidation products (\% of lignin total weight) in fresh Cyperaceae stems and peat samples from Tritrivakely marsh, Madagascar ${ }^{\mathrm{a}}$

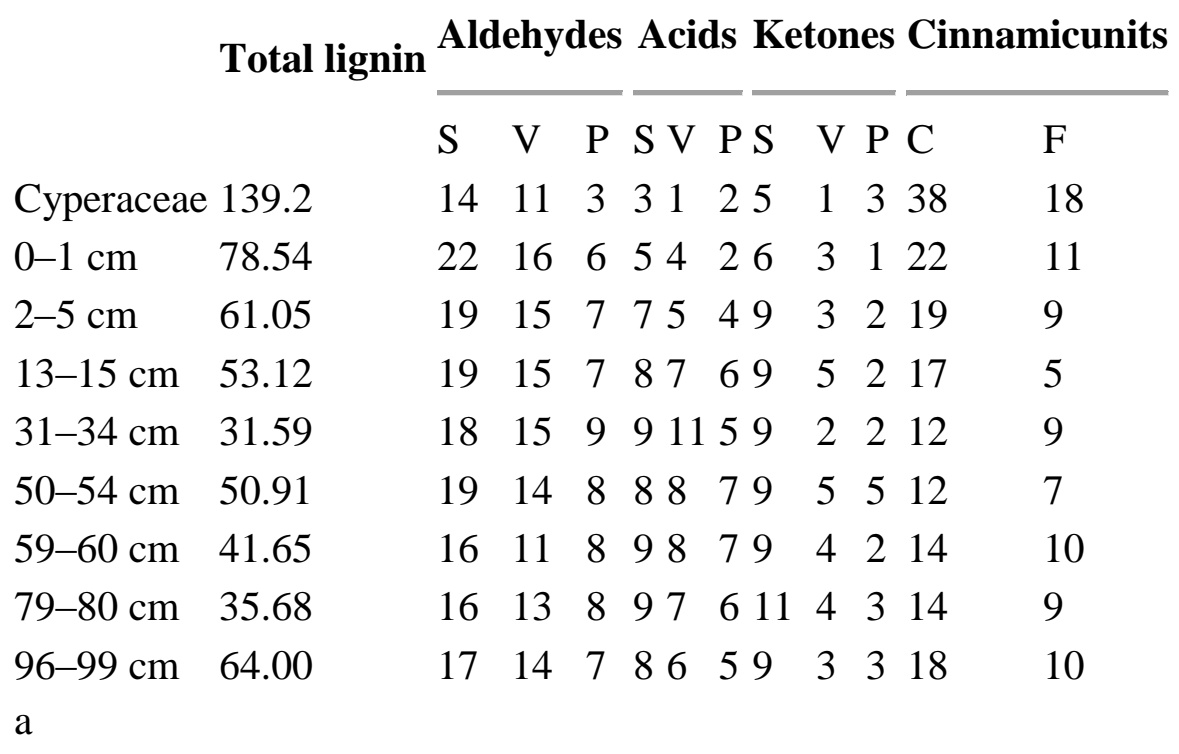

$\mathrm{S}$ : syringic phenols, $\mathrm{V}$ : vanillic phenols, $\mathrm{P}$ : $p$-hydroxybenzoic phenols, C: coumaric acids, F: ferulic acids.

By comparison with the fresh plants, the amount of lignin substantially decreases in the upper centimeter of the peat $(78.5 \mathrm{mg} / \mathrm{g}$ vs $139.2 \mathrm{mg} / \mathrm{g}$ in the material from the living Cyperaceae; Table 3). This decrease continues downward and a value of ca. $30 \mathrm{mg} / \mathrm{g}$ is noted at $31-34 \mathrm{~cm}$ (Table 3). Below, the amount of lignin increases, especially in the deepest sample $(64 \mathrm{mg} / \mathrm{g}$ at 96-99 cm). The decrease observed in the upper part of the studied section should chiefly originate from the progress of lignin alteration and also from increasing dilution by algal material. The trend observed in the lower part probably reflects increasing relative inputs of lignin due to lower dilution by non-ligneous material like phytoplankton, in agreement with $\mathrm{HI}$ and $\mathrm{C} / \mathrm{N}$ values discussed above.

All along the section, the abundances of vanillic, syringic and cinnamic units are wellcorrelated with the total amount of lignin [Fig. 4(a), (b), (c)]. Such a lack of significant changes in lignin composition indicates that no substantial changes in higher plant sources took place during the deposition of the studied peat section. In contrast, there is no tight correlation between $p$-hydroxybenzoic units and total lignin [Fig. 4(d)]. Some of the $p$ hydroxybenzoic compounds are thus probably derived from additional source(s) such as phytoplankton, as demonstrated by Hedges et al. (1988b) for samples collected in sediment traps in a marine bay. The latter authors demonstrated that the $p$-hydroxybenzoic acid and the 
$p$-hydroxybenzaldehyde in these samples chiefly originated from sources other than lignin, such as plankton, whereas the $p$-hydroxyacetophenone was mainly derived from lignin. Our data (Table 3) can be interpreted in the same way.
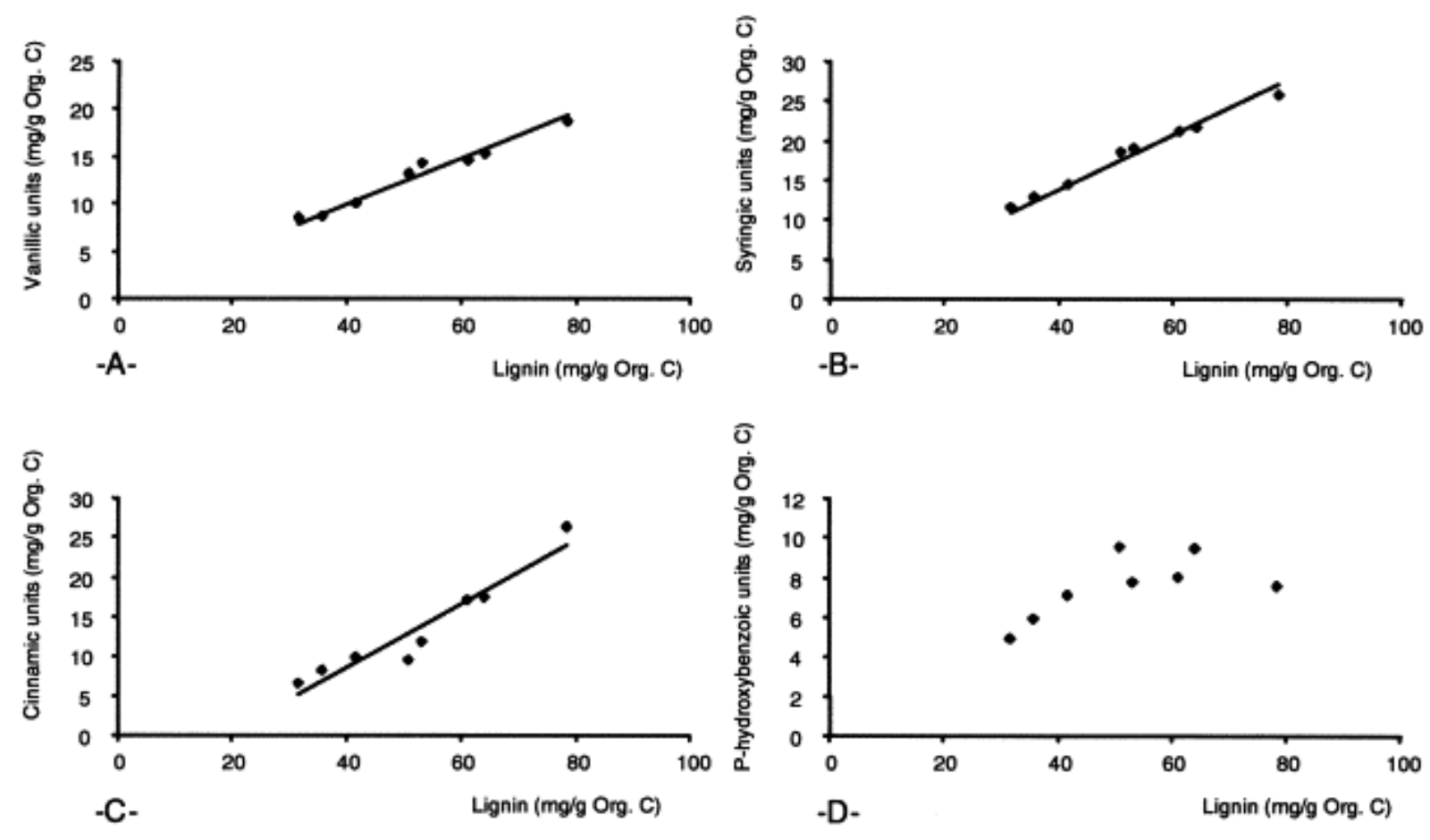

Fig. 4. Relationships between total lignin content and vanillic (A), syringic (B), cinnamic (C) and $p$-hydroxybenzoic (D) monomers of lignin in peat samples from Tritrivakely marsh, Madagascar.

In addition, the acid/aldehyde ratio of vanillic and syringic units is inversely correlated with the amount of total lignin (Fig. 5). The latter feature suggests that the depolymerisation of lignin is initiated by the oxidation of aldehydes which leads to the production of benzoic acids such as vanillic and syringic acids which are rapidly mineralised. In subaerial terrestrial environment, such degradation is generally mediated by white-rot fungi (Hedges, Blanchette, Weliky \& Devol, 1998a and Higuchi, 1990). At present, in Tritrivakely marsh, important seasonal variations of the watertable occur and drying of the surface peat was observed, for example in November 1992. During such dry periods an efficient degradation of lignin by white-rot fungi may have occurred, essentially at the top of the profile. Then, translocation of the resulting soluble acid monomers or oligomers of lignin down to deeper horizons of the peat may have occurred, followed by mineralisation by anaerobic bacteria (Young and Frazer, 1987). 


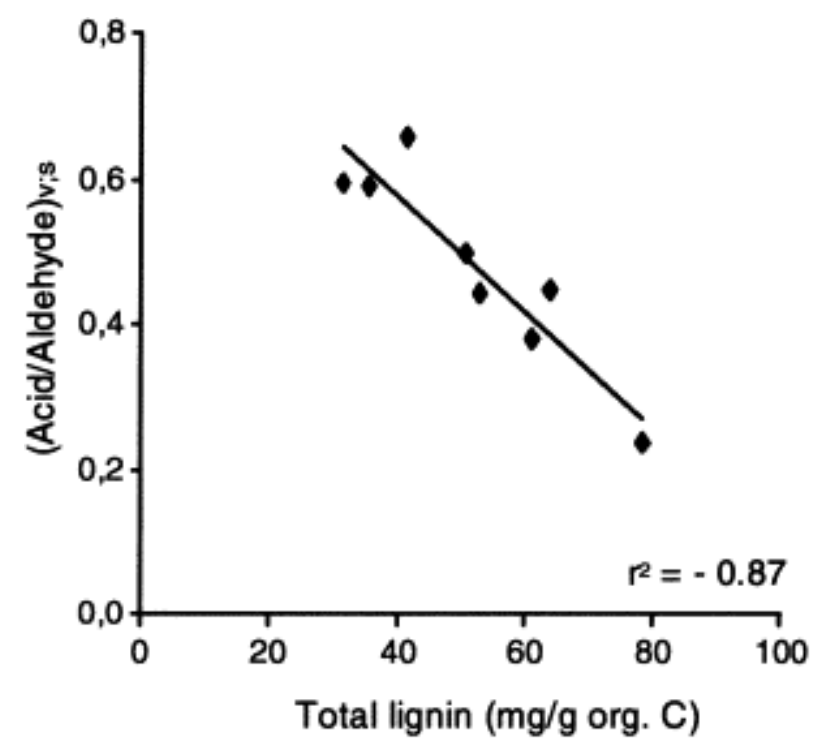

Fig. 5. Relationship between total lignin content and the acid / aldehyde ratio of syringic and vanillic monomers of lignin in peat samples from Tritrivakely marsh, Madagascar.

Acid/aldehyde ratio of syringic and vanillic monomers thus appears as an index of lignin oxidative depolymerisation, and hence as a criterion of alteration intensity of initial plant tissues. This alteration essentially results from microbial activity which can be fungal and bacterial for lignin, as discussed above, but which is mainly bacterial in the case of hemicelluloses. The bacterial degradation of hemicelluloses is reflected by the formation of sugars such as mannose, rhamnose and non-cellulosic glucose. Indeed, the (mannose+rhamnose+non cellulosic glucose/total sugars) ratio is positively correlated with the (acid/aldehyde) $)_{v ; s}$ ratio (Fig. 6). These two ratios can be, therefore, considered as markers of degradation of the tissues of the Cyperaceae by microbial activities. 


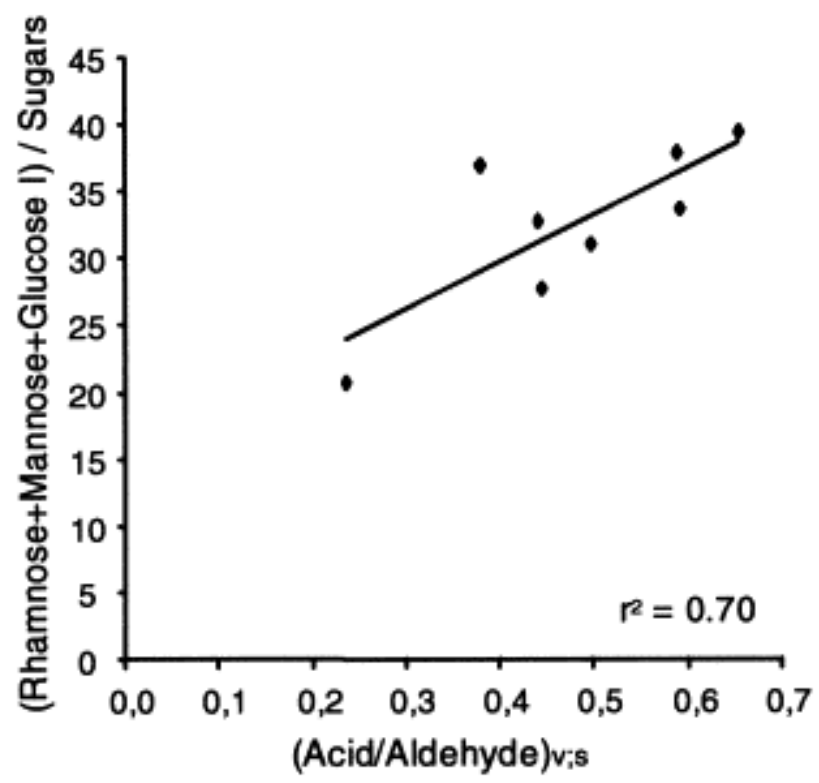

Fig. 6. Relationship between acid/aldehyde ratio of syringic and vanillic monomers (index of lignin oxidative depolymerisation) and (mannose+rhamnose+non-cellulosic glucose)/total sugar ratio (reflecting bacterial degradation of hemicelluloses) in peat samples from Tritrivakely marsh, Madagascar.

\subsection{Pyrolysis of hydrolysed peats (hp)}

The insoluble materials obtained after lipid extraction and acid hydrolysis of two peat samples from the upper part (30-34 cm section) and the lower part (79-80 cm section) of the profile, representing the intervals above and below the 1500 years timeline, termed hp- 1 and hp- 2 , respectively, were submitted to "off-line" pyrolyses. The trapped products, generated at $400^{\circ} \mathrm{C}$, were identified by GC/MS. This study was performed in order to compare the molecular information recorded by hp- 1 and hp- 2 and by the hydrolysable components examined above. In addition, the two peat samples were examined by elemental analysis and FTIR before any treatment.

\subsubsection{Elemental analysis}

The low amount of ash in both peat samples reflects the large predominance of OM over mineral matter in this material (Table 4). According to light microscopy observations the mineral matter mainly consists of biogenic silica (diatom tests and spicules of sponges). O/C and $\mathrm{H} / \mathrm{C}$ atomic ratios show high oxygen and hydrogen contents for the two peat samples, consistent with the immaturity of this material. The values of the $\mathrm{H} / \mathrm{C}$ ratio, which appear rather high for continental peats, could at least partly be explained by the admixture of aliphatic algal components. This interpretation is consistent with the presence of algae shown by microscopic observations. In agreement with $\mathrm{HI}$ and $\mathrm{C} / \mathrm{N}$ values previously discussed, suggesting a larger contribution of aliphatic algal components in the upper part of the section, a higher $\mathrm{H} / \mathrm{C}$ ratio is noted for sample- 1 . 
Table 4. Elemental composition (wt\%) and atomic ratios of the two peat samples from Tritrivakely marsh, Madagascar, selected for pyrolytic studies

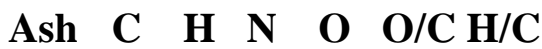

Sample $1(30-34 \mathrm{~cm}) 10.546 .76 .14 .132 .60 .521 .56$

Sample $2(79-80 \mathrm{~cm}) 9.3 \quad 48.96 .23 .631 .90 .491 .51$

\subsubsection{Infra-red spectroscopy}

The IR spectra of both peat samples (Fig. 7, sample-1-A and sample-2-A) display numerous absorption bands indicative of the presence of various functional groups as expected for immature OM. The two spectra show the same general pattern and main absorptions.
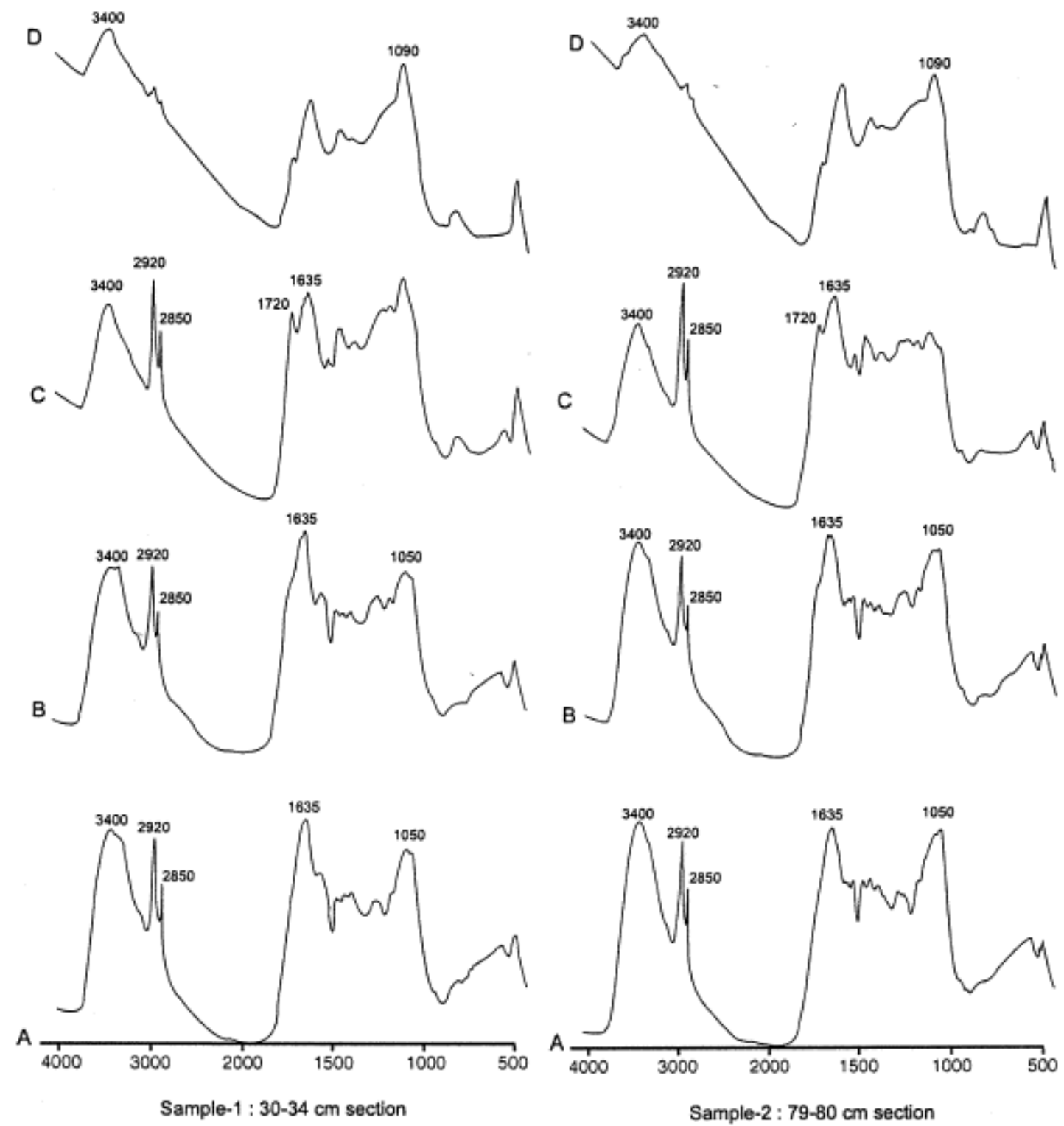

Fig. 7. FTIR spectra of the two peat samples selected for pyrolytic studies (sample-1, 30-34 cm section; sample-2, 79-80 cm section). (A) bulk peats, (B) solid residues after lipid removal and acid hydrolysis, (C) solid residues after pyrolysis at $300^{\circ} \mathrm{C}$, (D) solid residues after pyrolysis at $400^{\circ} \mathrm{C}$. 
The strong bands at 1040 and $3400 \mathrm{~cm}^{-1}$ should at least partly be related to polysaccharides (vC-O and $v \mathrm{O}-\mathrm{H}$, respectively). The band at $1040 \mathrm{~cm}^{-1}$ also shows the characteristic shoulders of cellulose, the main polysaccharide of ligno-cellulosic cell walls of higher plants (Given et al., 1984). The relative intensity of the typical bands of aliphatic groups at 2850 and $2920 \mathrm{~cm}^{-1}$ is unusually high for peat samples. This is most probably due to the presence of the hydrogen-rich algal material mentioned above. Based on the relative importance of these bands and of those characteristic of cellulose, sample-1 $(30-34 \mathrm{~cm})$ appears relatively enriched in aliphatic moieties compared with sample-2 $(79-80 \mathrm{~cm})$, which is in agreement with the above discussion on $\mathrm{H} / \mathrm{C}$ ratios and $\mathrm{HI}$ values, whereas the relative abundance of cellulose is lower.

Another difference between the two peat samples is concerned with the absorptions at 1635 , 1547 and $1226 \mathrm{~cm}^{-1}$ which can be ascribed to proteins (Disnar, Trichet, 1980 and Gerasimowicz, Byler \& Susi, 1986). The higher relative intensity of these bands in sample-1 than in sample- 2 is consistent with a higher protein content in the former. Such a difference is also supported by $\mathrm{N}$ contents of 4.1 and $3.6 \mathrm{wt} \%$, respectively, and by a lower $\mathrm{C} / \mathrm{N}$ ratio for sample- 1 .

The spectra of sample-1 and sample-2 obtained after free lipid extraction and acid hydrolysis [(Fig. 7, sample-1(B) and sample-2(B)] show that the removal of polysaccharides was more efficient in the former, as indicated by the greater decrease in the relative intensity of the 1040 and $3400 \mathrm{~cm}^{-1}$ bands when compared with the absorptions of the aliphatic moieties at 2850 and $2920 \mathrm{~cm}^{-1}$. Due to the relatively mild hydrolysis conditions used, the removed polysaccharides most probably corresponded to the easily hydrolysable hemicelluloses and to sugars from the cell wall of bacteria and microalgae. Indeed, the strong absorptions of cellulose still observed around $1040 \mathrm{~cm}^{-1}$ and the importance of the bands ascribed to proteins indicate that both types of moieties are resistant to the rather mild conditions used for the hydrolysis. In addition, the relative intensity of the $1040 \mathrm{~cm}^{-1}$ band in spectra 1-B and 2-B shows that cellulose content is higher in sample-2. This higher relative abundance, despite burial at a greater depth, can be explained by original sedimentary inputs richer in cellulose for sample-2, due to a lesser dilution of vascular plant components by aliphatic algal constituents in the deeper part of the peat profile.

After pyrolysis at $300^{\circ} \mathrm{C}$ [Fig. 7, sample-1(C) and sample-2(C)], the strong absorptions corresponding to cellulose and proteins are no longer observed, as a result of the thermal cracking that occurs at such a temperature (Disnar and Trichet, 1984). The absorption of biogenic amorphous silica $\left(\sim 1110 \mathrm{~cm}^{-1}\right)$, so far hidden by the absorption of polysaccharides, now appears. The intensity of this band is more important in the case of sample-1, thus reflecting a higher quantity of silica. This is confirmed by mass calculations indicating that sample- 1 and sample- 2 contain ca. 36 and $20 \%$ of amorphous silica, respectively. Protein removal unmasks the bands due to aromatic components at ca. 1510 and $1620 \mathrm{~cm}^{-1}$. The latter bands and the intense absorption retained at $3400 \mathrm{~cm}^{-1}$ probably reflect the presence of phenolic groups from lignins. In fact, as shown by the analysis of the pyrolysates obtained at $400^{\circ} \mathrm{C}$, see below, such groups survived the treatment at $300^{\circ} \mathrm{C}$ along with aliphatic moieties.

The spectra of the insoluble residues obtained after pyrolysis at $400^{\circ} \mathrm{C}$ [Fig. 7, sample-1(D) and sample-2(D)] are dominated by bands at ca. 1600 and $1100 \mathrm{~cm}^{-1}$ that correspond to aromatic groups and silica, respectively. Phenolic and aliphatic moieties have been eliminated during the second thermal treament. 


\subsubsection{Analysis of pyrolysates}

GC-MS analysis of the trapped fraction obtained by pyrolysis at $400^{\circ} \mathrm{C}$ of sample- 1 and sample- 2 showed three major types of products : $n$-alkanes, $n$-alk-1-enes and phenols. In both cases, the total ion current (TIC) trace of the pyrolysate is dominated by $n$-alkane/ $n$-alk-1-ene doublets up to $\mathrm{C}_{32}$, with no significant odd- or even-carbon-number predominance (Fig. 8). Such series of doublets with no predominance are commonly observed in pyrolysates of sedimentary OM (e.g. Largeau et al., 1986) and they are derived from the homolytic cleavage of unbranched alkyl chains. Two origins can be considered for these polymethylenic chains in sample-1 and sample-2 : 

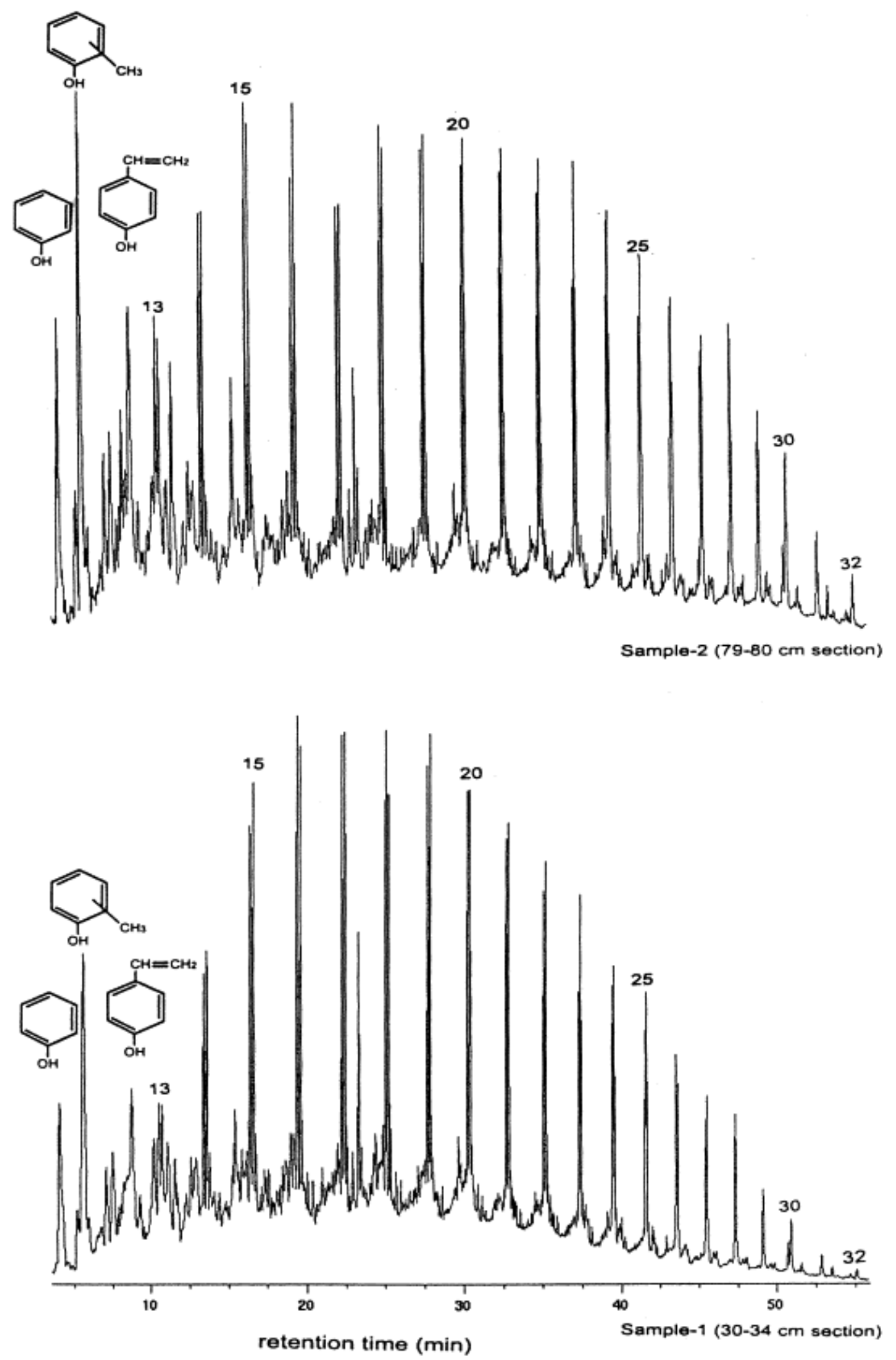

Fig. 8. Total ion current (TIC) traces of pyrolysis products obtained at $400^{\circ} \mathrm{C}$ from insoluble residues after lipid removal and acid hydrolysis of the two selected peat samples (sample-1, 30-34 cm section; sample-2, 79-80 cm section). Structures of major phenolic compounds are indicated. Numbers indicate chain length of $n$-alkane/n-alk-1-ene doublets. 
Firstly, lipidic components that have been incorporated to the insoluble material as a result of condensation reactions. Such reactions are known to be important during early diagenesis (Tissot and Welte, 1984) and extensive condensation processes, resulting in the incorporation of various lipids into insoluble refractory structures, were observed, for example, upon diagenesis of microalgal biomass (Derenne et al., 1997). Based on the unbranched nature of their alkyl chains, these condensed lipids may originate from microalgae (Weete, 1976 and Meyers, Ishiwatari, 1993) and/or from higher plants (Tulloch, 1976 and Meyers, Ishiwatari, 1993). In contrast, a bacterial origin is unlikely since a number of bacterial lipids are characterised by the presence of branched chains (Albro, 1976).

Secondly, insoluble refractory macromolecular components of microalgae or higher plants based on a network of polymethylenic chains. The occurrence of highly aliphatic, nonhydrolysable, biomacromolecules, termed algaenans (Tegelaar et al., 1989a), has been recognised in the cell walls of a number of microalgae (reviewed in Derenne et al. 1992 and de Leeuw \& Largeau, 1993). As already mentioned, light microscopy observations showed the presence of diatoms and of green microalgae (Botryococcus braunii) in the Tritrivakely section. Diatoms only occur in the upper part of the section, furthermore recent studies indicate that such microalgae are probably unable to produce algaenans (Gelin et al., 1999). In contrast, B. braunii is well known for its conspicuous production of algaenan ( Berkaloff, Casadevall, Largeau, Metzger, Peracca \& Virlet, 1983, Kadouri, Derenne, Largeau, Casadevall \& Berkaloff, 1988 and Derenne, Largeau, Casadevall \& Berkaloff, 1989) and a low but significant contribution of B. braunii was observed throughout the section. Highly aliphatic, refractory, macromolecular components have also been identified in the cuticles and periderm layers of a number of higher plants ( Nip, Tegelaar, Brinkhuis, Leeuw, Schenk \& Holloway, 1986, Tegelaar et al. 1989b and Tegelaar, Hollman, Van Der Vegt, de Leeuw \& Holloway, 1995). Such non-hydrolysable biomacromolecules were termed cutans and suberans, respectively (Tegelaar et al., 1989a). B. braunii algaenans, as well as cutans and suberans, produce large amounts of $n$-alkanes and $n$-alk-1-enes upon pyrolysis ( Largeau, Derenne, Casadevall, Kadouri \& Sellier, 1986, Nip, Tegelaar, Brinkhuis, Leeuw, Schenk \& Holloway, 1986, Kadouri, Derenne, Largeau, Casadevall \& Berkaloff, 1988, Tegelaar, Matthezing, Jansen, Horsfield, de Leeuw, 1989 and Tegelaar, Hollman, Van Der Vegt, de Leeuw \& Holloway, 1995). Furthermore, the doublets thus generated exhibit an extended carbon range and a large contribution of $\mathrm{C}_{20+}$ compounds. Cutans, suberans and algaenans are characterised by a very high resistance to diagenetic degradation and their chemical composition can remain almost unaltered following fossilisation, as demonstrated, for example, by comparison of algaenans isolated from extant $B$. braunii and of organic matter in Botryococcus-rich immature sedimentary rocks (e.g. Largeau, Derenne, Casadevall, Kadouri $\&$ Sellier, 1986 and Derenne et al. 1997). The presence of such refractory macromolecules is also associated with an excellent preservation of morphological features, as noted for cutancontaining cuticles (e.g. Nip et al., 1987). Similarly, the morphological features of B. braunii colonies are also perfectly retained in the fossil record, in a number of deposits (e.g. Largeau, Derenne et al. 1990 and Derenne et al. 1997), since the algaenan-composed cell walls build up the matrix of these colonies and are responsible for their typical shape (Berkaloff et al., 1983). The occurrence of well-preserved colonies of $B$. braunii throughout the section indicates that such walls were not significantly affected under the diagenetic conditions encountered during deposition in the marsh. Furthermore, histochemical staining techniques in TEM revealed in the OM flakes bioresistant lipo-polysaccharidic laminae probably inherited from higher plants (Laggoun-Défarge et al., 1999), especially from periderm tissues. Accordingly, it appears that the $n$-alkane/ $n$-alk-1-ene doublets in the pyrolysates of sample- 1 and sample- 2 originate from the cracking of not only $B$. braunii algaenan but also of higher plant suberans. 
Further information on the origin of these doublets and on the differences between the two peat samples was provided by their distributions. Substantial differences in $n$-alkane $/ n$-alk-1ene distribution are noted in the two pyrolysates; long chain compounds are relatively more abundant in the case of sample-2 (Fig. 8). Indeed, the $\mathrm{C}_{23}-\mathrm{C}_{32}$ components account for ca. $40 \%$ of the total doublets for the latter against ca. $28 \%$ in the trapped pyrolysate from sample1. Such a difference suggests, firstly, that $B$. braunii algaenan and higher plant suberans were not the major source of the doublets since, in that case, similar distributions should be observed. Accordingly, alkyl chains from condensed lipids are probably an important sources for both residues. Secondly, the above differences in doublet distribution probably reflect differences in the relative contribution of microalga and higher plant components to the condensed lipids. Indeed, the lipids of most microalgae (such as hydrocarbons, fatty acids and fatty alcohols) are characterised by shorter alkyl chains when compared to the corresponding lipids of higher plants ( Tulloch, 1976 and Weete, 1976). Thus, for example, $\mathrm{C}_{24+}$ fatty acids are commonly observed in vascular plants whereas such long chain compound are usually absent in microalgae. Accordingly, the doublet distributions observed in the two pyrolysates and their differences suggest that (i) the contribution of moieties derived from higher plants to the condensed lipids was relatively higher in sample- 2 than in sample-1, as shown by the above mentioned higher relative abundance of $\mathrm{C}_{22+}$ compounds in $n$-alkane/n-alk-1-ene doublets and (ii) microalgae were, nevertheless, major contributors to the condensed lipids in both cases, as shown by the predominance of $\mathrm{C}_{23}$ - compounds in these doublets. Some diatoms can accumulate especially large amounts of lipids, especially fatty acid derivatives (Aaronson et al., 1980). Therefore, a part of the condensed algal lipids probably originated from diatoms in the case of sample- 1 which contains, as shown by light microscopy observations, a significant amount of diatoms. Other species of microalgae were also probably living in the lake at the time of deposition of both peat samples and their lipids were probably incorporated during the condensation processes. However, unlike diatoms and B. braunii, the latter species were devoid of mineral exoskeleton and of algaenan-composed cell walls and none of their morphological features were retained.

The TIC trace of both pyrolysates also shows relatively intense peaks corresponding to phenol and substituted phenols (Fig. 8). The alkyl phenols, identified by mass fragmentogram $\mathrm{m} / \mathrm{z}$ 107, are dominated by a peak corresponding to the co-elution of meta- and para-cresol. In the trapped products from sample-2 pyrolysis, the latter peak is, in fact, the most intense one on the TIC trace (Fig. 8, sample 2). The abundance of the alkylphenols rapidly decreases with the number of alkyl carbons and the $\mathrm{C}_{3}$-homologues only occur in negligible amount.

Methoxyphenols, catechols (dihydroxybenzenes) and vinylphenols were also identified in the two pyrolysates (Fig. 9). Alkylphenols, along with methoxyphenols and catechols, are typical pyrolysis products of lignin (e.g. Saiz-Jimenez, Boon, Hedges, Hessels \& de Leeuw, 1987 and Hatcher \& Spiker, 1988). Furthermore, 4-vinylphenol and 4-vinylmethoxyphenol in pyrolysates are considered as markers of lignin from monocotyledon plants like Cyperaceae (Saiz-Jimenez and de Leeuw, 1986) since they are derived from cinnamic units. All the above phenolic compounds exhibit similar relative abundances in both pyrolysates. Such similarities confirm previously discussed results on lignin composition, derived from $\mathrm{CuO}$ oxidation; no significant changes in lignin composition and hence in higher plant sources took place during deposition of the studied section. It is well documented that methoxy groups tend to be eliminated during diagenetic alteration of lignin ( Saiz-Jimenez \& de Leeuw, 1986, Nip, De Leeuw \& Schenck, 1987, Saiz-Jimenez, Boon, Hedges, Hessels \& de Leeuw, 1987, Hatcher \& Spiker, 1988 and Hatcher \& Clifford, 1997). Accordingly, the above observations, on the phenolic constituents of the two pyrolysates, indicate a substantial contribution of lignin with a low degree of alteration in sample-1 and sample-2. However, in agreement with previous 
indications on the relative contributions of Cyperaceae and microalgae, this lignin fraction appears relatively more abundant in the case of sample-2. This difference is illustrated by higher phenol $/ n$-heptadecane and vinylphenol $/ n$-heptadecane ratios in hp- 2 pyrolysate $(1.16$ instead of 0.6 and 0.49 instead of 0.26 , respectively).

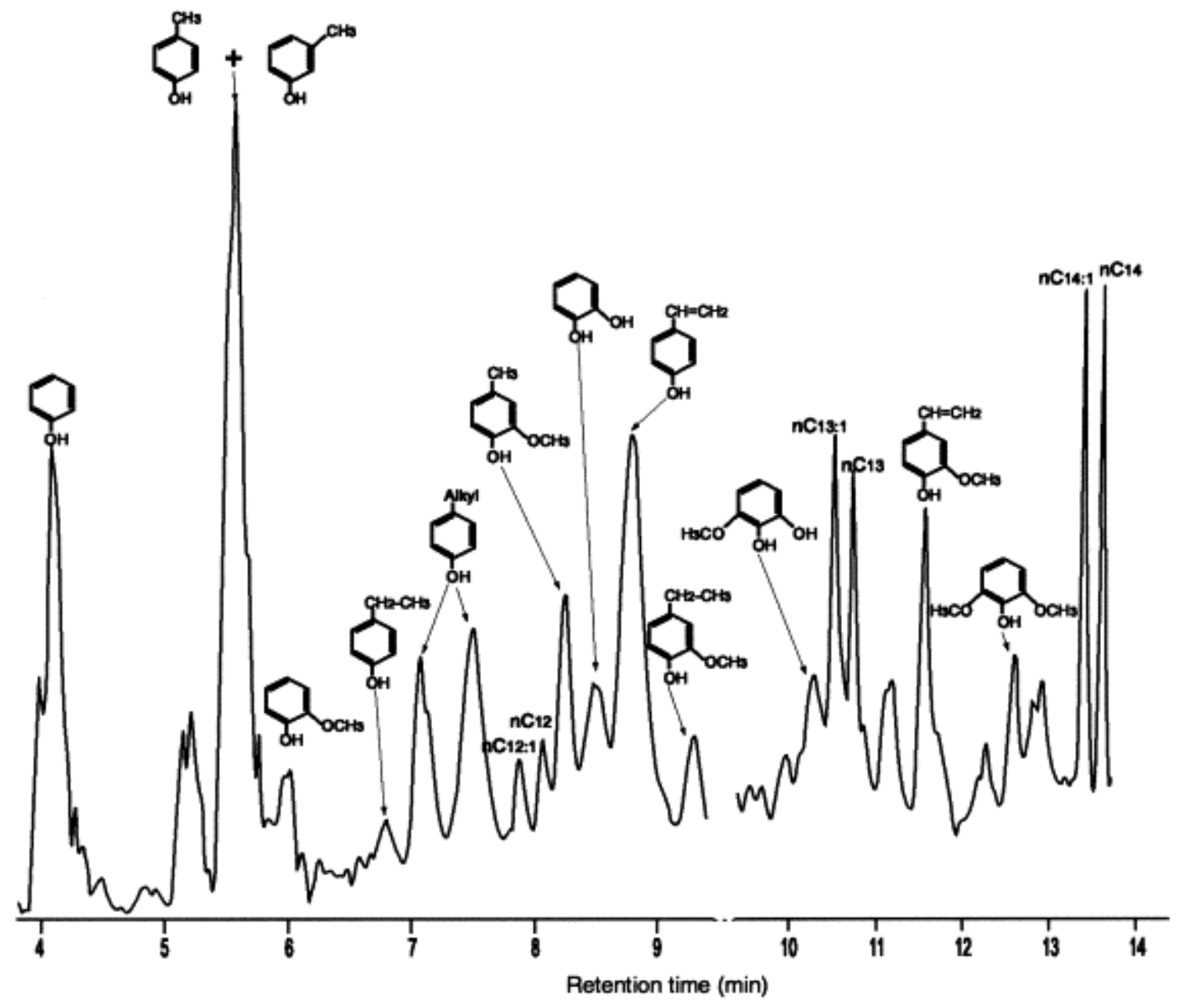

Fig. 9. Partial TIC trace of pyrolysate of sample-2 (79-80 cm section) showing phenolic compounds.

\section{Conclusions}

The main results concerning OM sources and OM degradation in the one metre core from Tritivakely Marsh, obtained by a combination of light microscopy observations, bulk analyses, infra-red spectroscopy, hydrolysis of sugars, oxidation of lignin and pyrolyses, are as summarised below:

The lignin of the Cyperaceae that live in the marsh at present is characterised by high contents of cinnamic units. The saccharides in these plants reveal high amounts of xylose and arabinose which are the main components of hemicelluloses. Peat recorded these specific signatures since abundances of cinnamic units and of xylose+arabinose are tightly correlated (Fig. 10) (correlation coefficient=0.96). Such a correlation, 
added to the lack of significant changes in lignin composition indicated by $\mathrm{CuO}$ oxidation and pyrolyses, suggests that the floristic composition of the vegetation probably remained unchanged during the considered deposition period, i.e. from 2,300 years B.P. Fig. 10 also illustrates pronounced changes that took place ca. 1500 years B.P. (i.e. around $50 \mathrm{~cm}$ depth) and which probably reflect, as described later on, a regional climatic change.

Cinnamic units

(\% Lignin)

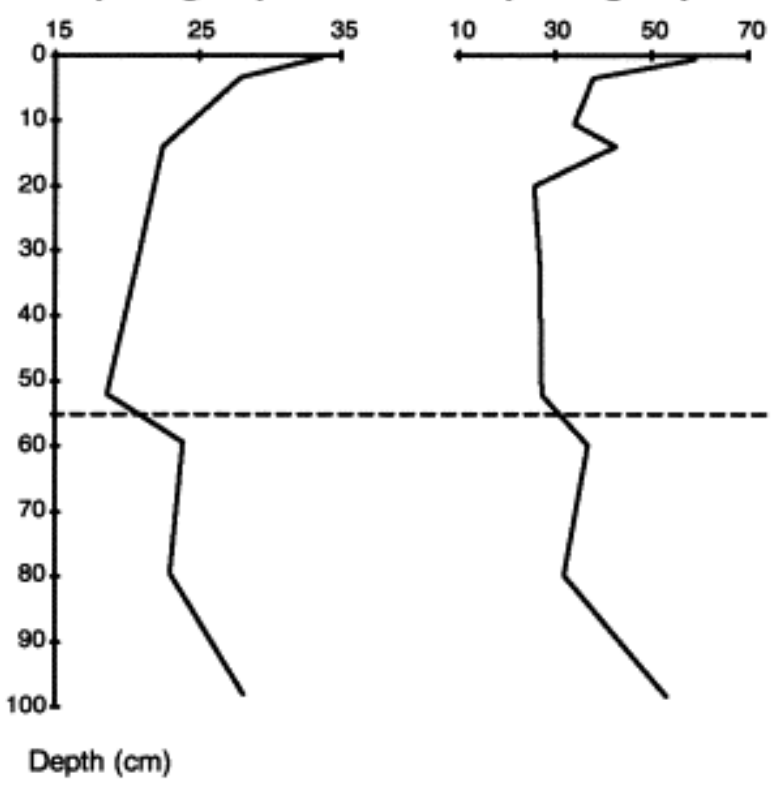

Fig. 10. Correlations between cinnamic monomers of lignin and hemicellulosic sugars (xylose and arabinose) vs depth. The dashed line separates the two accumulation periods related to the environmental variation that occurred ca. 1500 year B.P. 
The lignin of the Cyperaceae that live in the marsh at present is characterised by high contents of cinnamic units. The saccharides in these plants reveal high amounts of xylose and arabinose which are the main components of hemicelluloses. Peat recorded these specific signatures since abundances of cinnamic units and of xylose+arabinose are tightly correlated (Fig. 10) (correlation coefficient=0.96). Such a correlation, added to the lack of significant changes in lignin composition indicated by $\mathrm{CuO}$ oxidation and pyrolyses, suggests that the floristic composition of the vegetation probably remained unchanged during the considered deposition period, i.e. from 2,300 years B.P. Fig. 10 also illustrates pronounced changes that took place ca. 1500 years B.P. (i.e. around $50 \mathrm{~cm}$ depth) and which probably reflect, as described later on, a regional climatic change.

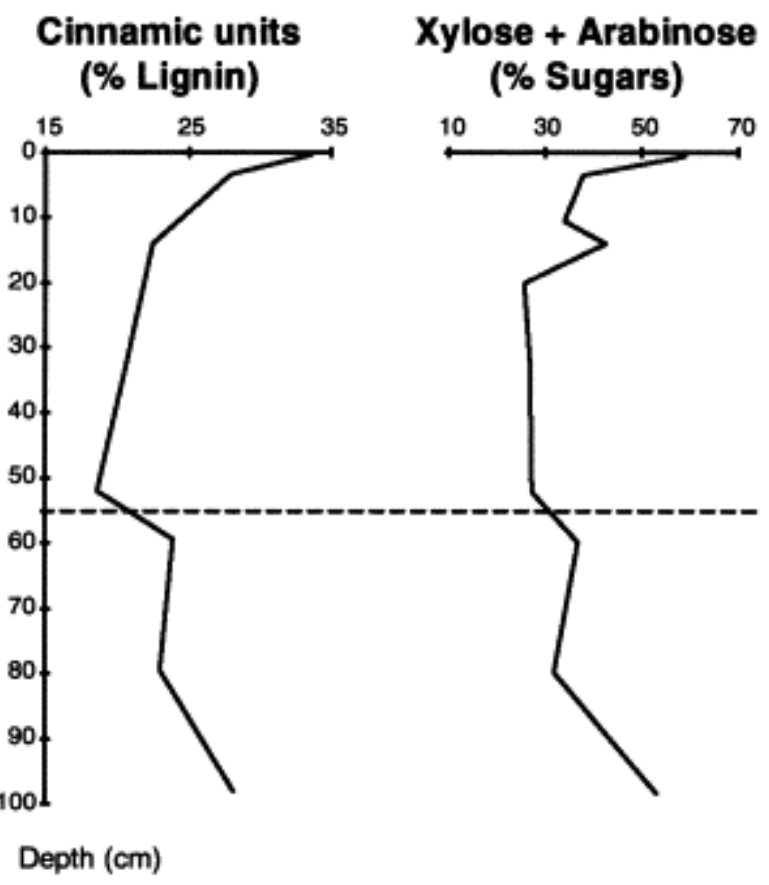

Fig. 10. Correlations between cinnamic monomers of lignin and hemicellulosic sugars (xylose and arabinose) vs depth. The dashed line separates the two accumulation periods related to the environmental variation that occurred ca. 1500 year B.P.

Figure options

The correlations observed between rhamnose and mannose and between mannose and non-cellulosic glucose indicate that these monosaccharides probably have a common origin and are mostly derived from bacteria.

Sugar analysis showed high proportions of galactose, especially in the upper part of the profile ( $\leqslant 50 \mathrm{~cm}$ depth) where a substantial diatom content was observed by light microscopy. Moreover, galactose, whose presence is usually attributed to bacterial activity (Oades, 1984 and Guggenberger, christensen \& Zech, 1994), is not correlated 
with mannose or rhamnose. Accordingly, galactose is likely to be a marker of algal source in the core, especially of diatoms.

The $n$-alkane/ $n$-alk-1-ene doublets that dominate the trapped pyrolysates of hydrolysed peat samples reflect the contribution of (1) B. braunii algaenan and higher plant suberans (2) condensed lipids mostly derived from microalgae (probably including diatoms in the upper part of the profile), and to a lesser extent from higher plants.

Degradation mainly takes place at the top of the peat. As shown by microscopic observations, this extensive early diagenetic alteration leads to a complete destructuration of the ligno-cellulosic tissues of the Cyperaceae which are transformed into reddish amorphous aggregates that account for the bulk of total OM all along the core, including the $0-1 \mathrm{~cm}$ layer.

Cellulose and total polysaccharides are highly degraded as early as the first centimetres of the core but they do not undergo further extensive degradation in deeper samples.

Lignin is also strongly degraded, although to a lesser extent than polysaccharides, in the first centimetres of the core

Acid/aldehyde ratios of syringic and vanillic monomers (index of lignin oxidative depolymerisation) and mannose+rhamnose+non cellulosic glucose/total sugars ratios (reflecting bacterial degradation of hemicelluloses) are positively correlated. Both ratios can thus be considered as markers of degradation of the Cyperaceae tissues by microbial activities.

The upper part of the core $(0-\mathrm{ca} .50 \mathrm{~cm})$ is characterised by a more important dilution of Cyperaceae-derived compounds by OM from microalgae when compared with deeper samples. Such a difference was recorded in peat in several ways: bulk features, hydrolysable sugars, lignin oxidation products and pyrolysis products from hydrolysed samples.

The above difference probably reflects changes in environmental conditions and two accumulation periods can be distinguished in the core. The first one, between 2300 years B.P. and ca. 1500 years B.P. (100-ca. $50 \mathrm{~cm}$ depth), was a peaty phase in which 
the mean watertable was low and microalgal growth strongly limited. The second period, from ca. 1500 years B.P. to the present time, corresponds rather to a waterlogged marsh, in which a higher watertable was, if not permanent, at least longer lasting and allowed for a substantial production of algal biomass. The environmental variation thus recorded could correspond to a regional climatic change occurring around 1500 years BP.

\section{Acknowledgements}

We thank Marielle Hatton, Didier Kéravis and Yves Pouet for their assistance in laboratory analyses. We also thank Jacques Bertaux from ORSTOM, Bondy, France for his help and advices concerning FTIR analysis. This work was partly supported by "GdR 970" of CNRS. Drs. M. Kruge and P.F. van Bergen are acknowledged for their careful reviews and constructive comments.

\section{References}

S. Aaronson, T. Berner, Z. Dubinsky

Microalgae as a source of chemicals and natural products

G. Shelef, C.J. Soeder (Eds.), Algae Biomass, Elsevier, Amsterdam (1980), pp. 575-601

P.W. Albro

Bacterial waxes

P.E. Kolattukudy (Ed.), Chemistry and Biochemistry of Natural Waxes, Elsevier, Amsterdam (1976), pp. 419-439

R. Benner, A. MacCubbin, R.E. Hodson

Anaerobic biodegradation of the lignin and polysaccharide components of lignocellulose and synthetic lignin by sediment microflora

Applied Environmental Microbiology, 47 (1984), pp. 998-1004

C. Berkaloff, E. Casadevall, C. Largeau, P. Metzger, S. Peracca, J. Virlet

The resistant polymer of the walls of the hydrocarbon-rich alga Botryococcus braunii

Phytochemistry, 22 (1983), pp. 389-397

Besairie, H., 1946. La géologie de Madagascar. Travaux du Bureau Géologique No. 54, Tananarive.

P.O. Bethge, C. Holmström, S. Juhlin

Quantitative gas chromatography of mixtures of simple sugars

Svensk Papperstidning arg, 69 (1966), pp. 60-63

H.T.S. Boschker, E.M.J. Dekkers, R. Pel, T.E. Cappenberg

Sources of organic carbon in the littoral of Lake Gooimeer as indicated by stable carbon isotope and carbohydrate compositions

Biogeochemistry, 29 (1995), pp. 89-105 
S. Bourdon, F. Laggoun-Défarge, C. Chenu

Effets de la diagenèse précoce sur la matière organique sédimentaire d'origine

palustre. Exemple du lac Tritrivakely (Madagascar)

Bulletin de la Société géologique de France, 168 (5) (1997), pp. 565-572

D.A. Burney

Pre-settlement vegetation changes at Lake Tritrivakely, Madagascar

J.A. Coetze (Ed.), Palaeoecology of Africa, Balkema, Rotterdam (1987), pp. 351381

P. Chaperon, J. Danioux, L. Ferry

Fleuves et Rivières de Madagascar

ORSTOM, Paris (1993)

R.S. Clymo

Peat

A.J.P. Gore (Ed.), Ecosystems of the World. Mires: Swamp, Bog, Fen and Moor.

General Studies, Elsevier, Amsterdam (1983), pp. 159-224

P.J. Colberg, L.Y. Young

Biodegradation of lignin-derived molecules under anaerobic conditions

Canadian Journal of Microbiology, 28 (1982), pp. 886-889

J.W. de Leeuw, C. Largeau

A review of macromolecular organic compounds that comprise living organisms and their role in kerogen, coal and petroleum formation

M.H. Engels, S.A. Macko (Eds.), Organic Geochemistry, Plenum Press, New York (1993), pp. 23-72

S. Derenne, C. Largeau, E. Casadevall, C. Berkaloff

Occurrence of a resistant biopolymer in the $L$ race of Botryococcus braunii

Phytochemistry, 28 (1989), pp. 1137-1142

S. Derenne, C. Largeau, C. Berkaloff, B. Rousseau, C. Wilhelm, P. Hatcher Non-hydrolysable macromolecular constituents from outer walls of Chlorella fusca and Nanochlorum eucaryotum

Phytochemistry, 31 (1992), pp. 1923-1929

S. Derenne, C. Largeau, M. Hetényi, A. Brukner-Wein, J. Connan, B. Lugardon Chemical structure of the organic matter in a Pliocene maar-type oil shale.

Implicated Botryococcus races and formation pathways

Geochimica et Cosmochimica, 61 (1997), pp. 1879-1889

J.-R. Disnar, J. Trichet

Etude expérimentale de la fixation de métaux par un matériau sédimentaire actuel d'origine algaire-I. Isolement, purification et caractérisation de la matière organique

Geochimica et Cosmochimica Acta, 45 (1980), pp. 353-362 
J.-R. Disnar, J. Trichet

The influence of various divalent cations $\left(\mathrm{UO}_{2}{ }^{+2}, \mathrm{Cu}^{2+}, \mathrm{Pb}^{2+}, \mathrm{Co}^{2+}, \mathrm{Ni}^{2+}, \mathrm{Zn}^{2+}\right.$, $\mathrm{Mn}^{2+}$ ) on the thermally induced evolution of organic matter isolated from an algal mat

Organic Geochemistry, 6 (1984), pp. 865-874

Donque, G., 1975. Contribution géographique à l'étude du climat Malgache. $\mathrm{PhD}$ dissertation, University of Madagascar.

J.R. Ertel, J.I. Hedges

The lignin component of humic substances: distribution among soil and sedimentary humic, fulvic and base-insoluble fractions

Geochimica et Cosmochimica Acta, 48 (1984), pp. 2065-2074

Espitalié, J., Deroo, G., Marquis, F., 1985. La pyrolyse Rock Eval et ses applications. Revue de l'Institut Français du Pétrole 40, 563-579, 40, 755-784, 41, 73-89.

P. Farrimond, R.L. Flanagan

Lipid stratigraphy of a Flandrian peat bed (Northumberland, U.K.): comparison with the pollen record

The Holocene, 6 (1995), pp. 69-74

K.J. Ficken, K.E. Barber, G. Eglinton

Lipid biomarkers, $\delta{ }^{13} \mathrm{C}$ and plant macrofossil stratigraphy of a Scottish montane peat bog over the last two millenia

Organic Geochemistry, 28 (1998), pp. 217-237

F. Gasse, E. Van Campo

A 40,000-yr pollen and diatom record from lake Tritrivakely, Madagascar, in the southern tropics

Quaternary Research, 49 (1998), pp. 299-311

F. Gasse, E. Cortijo, J.-R. Disnar, L. Ferry, E. Gibert, C. Kissel et al.

A 36 kyear environmental record in the southern tropics: lake Tritrivakely

(Madagascar)

Comptes Rendus de l'Académie des Sciences (Paris), 318 (1994), pp. 1513-1519

F. Gelin, J.K. Volkman, C. Largeau, S. Derenne, J.S. Sinninghe Damsté, J.W. de Leeuw Distribution of aliphatic, non-hydrolysable biopolymers in marine microalgae

Organic Geochemistry, 30 (1999), pp. 147-159

W.V. Gerasimowicz, D.M. Byler, H. Susi

Resolution-Enhanced FT-IR spectra of soil constituents: humic acid Applied Spectroscopy, 40 (4) (1986), pp. 504-507

P.H. Given, W. Spackman, P.C. Painter, C.A. Rhoads, N.J. Ryan, L. Alemany et al. The fate of cellulose and lignin in peats: an exploratory study of the input to coalification

Organic Geochemistry, 6 (1984), pp. 399-407 
G. Guggenberger, B.T. Christensen, W. Zech

Land-use effects on the composition of organic matter in particle-size separates of soil: I. Lignin and carbohydrate signature

European Journal of Soil Science, 45 (1994), pp. 449-458

S.E. Hamilton, J.I. Hedges

The comparative geochemistries of lignins and carbohydrates in an anoxic fjord

Geochimica et Cosmochimica Acta, 52 (1988), pp. 129-142

P.G. Hatcher, D.J. Clifford

The organic geochemistry of coal: from plant materials to coal

Organic Geochemistry, 27 (1997), pp. 251-274

P.G. Hatcher, E.C. Spiker

Selective degradation of plant biomolecules

F.H. Frimmel, R.F Christman (Eds.), Humic Substances and Their Role in the

Environments, Wiley, New York (1988), pp. 59-74

J.I. Hedges, D.C. Mann

The lignin geochemistry of marine sediments from the southern Washington coast Geochimica et Cosmochimica Acta, 43 (1979), pp. 1809-1818

J.I. Hedges, J.R. Ertel

Characterization of lignin by gas capillary chromatography of cupric oxide oxidation products

Analytical Chemistry, 54 (1982), pp. 174-178

J.I. Hedges, J.R. Ertel, E.B. Leopold

Lignin geochemistry of a Late Quaternary sediment core from Lake Washington

Geochimica et Cosmochimica Acta, 46 (1982), pp. 1869-1877

J.I. Hedges, R.A. Blanchette, K. Weliky, A.H. Devol

Effects of fungal degradation on the $\mathrm{CuO}$ oxidation products of lignin: a controlled laboratory study

Geochimica et Cosmochimica Acta, 52 (1988), pp. 2717-2726

J.I. Hedges, W.A. Clark, G.L. Cowie

Organic matter sources to the water column and surficial sediments of a marine bay

Limnology and Oceanography, 33 (1988), pp. 1116-1136

R.E. Hicks, C.J. Owen, P. Aas

Deposition, resuspension, and decomposition of particulate organic matter in the sediments of Lake Itasca, Minnesota, USA

Hydrobiologia, 284 (1994), pp. 79-91

T. Higuchi

Lignin biochemistry: biosynthesis and biodegradation

Wood Science and Technology, 24 (1990), pp. 23-63 
A.Y. Huc

Sedimentology of organic matter

F.H. Frimmel, R.F. Christman (Eds.), Humic Substances and Their Role in the

Environments, Wiley, New York (1988), pp. 215-243

R. Ishiwatari, M. Uzaki

Diagenetic changes of lignin compounds in a more than 0.6 million-year-old lacustrine sediment (Lake Biwa, Japan)

Geochimica et Cosmochimica Acta, 51 (1987), pp. 321-328

A. Kadouri, S. Derenne, C. Largeau, E. Casadevall, C. Berkaloff

Resistant biopolymer in the outerwalls of Botryococcus braunii, B Race

Phytochemistry, 27 (1988), pp. 551-557

Laggoun-Défarge, F., Bourdon, S., Chenu, C., Défarge, C., Disnar, J.-R., 1999. Etude des transformations morphologiques précoces des tissus végétaux dans la tourbe du marécage de Tritrivakely (Madagascar). Apports des techniques de marquage histochimique en MET et du cryo-MEB haute résolution. In: Structure et Ultrastructure des Sols et des Organismes Vivants. Versailles (France), 20-21 November 1997. INRA (Ed.), Paris, 1999 (Les Colloques, No. 92). pp. 169-182.

C. Largeau, S. Derenne, E. Casadevall, A. Kadouri, N. Sellier

Pyrolysis of immature Torbanite and of the resistant biopolymer (PRBA) isolated from extant alga Botryococcus braunii. Mechanism of formation and structure of Torbanite

D. Leythaeuser, J. Rullkötter (Eds.), Advances in Organic Geochemistry, 1985, Organic Geochemistry 10, Pergamon Press, Oxford (1986), pp. 1023-1032

C. Largeau, S. Derenne, C. Clairay, E. Casadevall, J.-F. Raynaud, B. Lugardon, C. Berkaloff, M. Corolleur, B. Rousseau

Characterization of various kerogens by scanning electron microscopy (SEM) and transmission electron microscopy (TEM) - morphological relationships with resistant outer walls in extant microorganisms.

Mededelingen Rijks Geology Dienst, 45 (1990), pp. 91-101

Maman, O., 1997. Analyse des produits d'hydrolyse de la lignine par électrophorèse capillaire: application à la reconnaissance de signatures d'écosystèmes dans les sols, les paléosols et les sédiments. Unpublished PhD thesis, University of Orléans, p. 119.

O. Maman, F. Marseille, B. Guillet, J-R. Disnar, P. Morin

Separation of phenolic aldehydes, ketones and acids from lignin degradation by capillary zone electrophoresis

Journal of Chromatography A, 755 (1996), pp. 89-97

Maman, O., Guillet, B., Disnar, J.-R., Marseille, F. \& Mariotti, A., 1998. Lignin derived phenolic compounds extracted from soil organic matter as markers of past ecosystems. CD Rom proceedings of $16^{\text {th }}$ World Congress of Soil Science, Symposum 34, 6 p. 
P.A. Meyers, R. Ishiwatari

Lacustrine organic geochemistry - an overview of indicators of organic matter and diagenesis in lake sediments

Organic Geochemistry, 20 (1993), pp. 867-900

M.E.C. Moers, M. Baas, J.J. Boon, J.W. de Leeuw

Molecular characterization of total organic matter and carbohydrates in peat samples from a cypress swamp by pyrolysis-mass spectrometry and wet-chemical methods

Biogeochemistry, 11 (1990), pp. 251-277

M.E.C. Moers, M. Baas, J.W. de Leeuw, J.J. Boon, P.A. Schenck

Occurrence and origin of carbohydrates in peat samples from a red mangrove environment as reflected by abundances of neutral monosaccharides

Geochimica et Cosmochimica Acta, 54 (1990), pp. 2463-2472

M. Nip, E.W. Tegelaar, H. Brinkhuis, J.W. de Leeuw, P.A. Schenk, P.J. Holloway Analysis of modern and fossil plant cuticles by Curie-point Py-GC-MS: recognition of a new highly aliphatic and resistant biopolymer Organic Geochemistry, 10 (1986), pp. 769-778

M. Nip, J.W. de Leeuw, P.A. Schenck

Structural characterization of coals, coal macerals and their precursors by pyrolysis-gas chromatography-mass spectrometry

Coal Science Technology, 11 (1987), pp. 89-92

J.M. Oades

Soil organic matter and structural stability: mechanisms and implications for management

Plant and Soil, 76 (1984), pp. 319-337

W.H. Orem, S.M. Colman, H.E. Lerch

Lignin phenols in sediments of Lake Baikal, Siberia: application to

paleoenvironmental studies

Organic Geochemistry, 27 (1997), pp. 153-172

R. Pelet, G. Deroo

Vers une sédimentologie de la matière organique

Bulletin de la Société Géologique de France, 25 (1983), pp. 483-493

C. Saiz-Jimenez, J.W. de Leeuw

Lignin pyrolysis products: their structures and their significance as biomarkers

Organic Geochemistry, 10 (1986), pp. 869-876 
C. Saiz-Jimenez, J.J. Boon, J.I. Hedges, J.K.C. Hessels, J.W. de Leeuw

Chemical characterization of recent and buried woods by analytical pyrolysis.

Comparison of pyrolysis data with ${ }^{13} \mathrm{C}$ NMR and wet chemical data

Journal of Analytical and Applied Pyrolysis, 11 (1987), pp. 437-450

A. Sifeddine, F. Laggoun-Défarge, E. Lallier-Vergès, J.-R. Disnar, D. Williamson, F. Gasse

La sédimentation organique lacustre en zone tropicale sud au cours des 36000

dernières années (Lac de Tritrivakely, Madagascar)

Comptes Rendus de l'Académie des Sciences (Paris), 321 (1995), pp. 385-391

A.C. Sigléo

Biochemical components in suspended particles and colloids: carbohydrates in the Potomac and Patuxent Estuaries

Organic Geochemistry, 24 (1996), pp. 83-93

E.W. Tegelaar, R.M. Matthezing, B.H. Jansen, B. Horsfield, J.W. de Leeuw

Possible origin of $n$-alkanes in high-wax crude oils

Nature, 342 (1989), pp. 529-531

E.W. Tegelaar, J.W. de Leeuw, S. Derenne, C. Largeau

A reappraisal of kerogen formation

Geochimica et Cosmochimica Acta, 53 (1989), pp. 3103-3106

E.W. Tegelaar, J.W. de Leeuw, C. Largeau, S. Derenne, H.R. Schulten, R. Müller et al. Scope and limitations of several pyrolysis methods in the structural elucidation of a macromolecular plant constituent in the leaf cuticle of Agave americana $L$. Journal of Analytical and Applied Pyrolysis, 15 (1989), pp. 29-54

E.W. Tegelaar, G. Hollman, P. Van Der Vegt, J.W. de Leeuw, P.J. Holloway Chemical characterization of the periderm tissue of some angiosperm species: recognition of an insoluble, non-hydrolysable, aliphatic biomacromolecule (suberan)

Organic Geochemistry, 23 (1995), pp. 239-250

B.P. Tissot, D.H. Welte

Petroleum Formation and Occurrence

(2nd Edition.)Springer, Berlin (1984)

C. Trouvé, J.-R. Disnar, A. Mariotti, B. Guillet

Changes in the amount and distribution of neutral monosaccharides of savanna soils after plantation of Pinus and Eucalyptus in the congo

European Journal of Soil Science, 47 (1996), pp. 51-59

A.P. Tulloch

Chemistry of waxes of higher plants

P.E. Kolattukudy (Ed.), Chemistry and Biochemistry of Natural Waxes, Elsevier, Amsterdam (1976), pp. 235-287 
J.E. Weete

Algal and fungal waxes

P.E. Kolattukudy (Ed.), Chemistry and Biochemistry of Natural Waxes, Elsevier, Amsterdam (1976), pp. 349-418

R.J. Wicks, M.A. Moran, L.J. Pittman, R.E. Hodson

Carbohydrates signatures of aquatic macrophytes and their dissolved degradation products as determined by a sensitive high-performance ion chromatography method

Applied Environmental Microbiology, 57 (1991), pp. 3135-3143

L.Y. Young, A.C. Frazer The fate of lignin and lignin-derived compounds in anaerobic environments Geomicrobiological Journal, 5 (1987), pp. 261-293 